\title{
STUDI PENGGUNAAN PACKING PLANT PADA DISTRIBUSI SEMEN DI KALIMANTAN MENGGUNAKAN METODE TRANSSHIPMENT: STUDI KASUS PT SEMEN GRESIK
}

\author{
Ikhyandini Garindia Atristyanti \\ Fakultas Ekonomi dan Bisnis Universitas Mercu Buana \\ Email: garindia@gmail.com
}

\begin{abstract}
As the largest cement producer in Indonesia, PT Semen Gresik Group has a distribution network spread across West and the eastern of Indonesia and dominate the national cement market share of about $45 \%$. To support the distribution of velocity throughout the whole country, a strategic step to do is build a packing plant in the area of distribution. The results of the annual analysis, moving closer packing plant to the distribution area can be a solution for efficiency of the transportation costs up to $43 \%$ compared to the situation before, and it will be the company's long-term strategic plan. This research will be carried out optimization of the allocation of cement distribution network in the Kalimantan. Designing a distribution network allocation transshipment model is the development of transport in linear programming models with the help of QM for Windows software. The expected output is the formation of an optimal distribution network with the minimum total cost. To determine the cost efficiency with the packing plant, the optimization model is made will be running four times as much computing. There are four scenarios used without removing the packing plant, with a packing plant in Banjarmasin, a packing plant in Banjarmasin and Pontianak, as well as a packing plant in Banjarmasin, Pontianak and Samarinda. The result of the four scenarios is known that with the packing plant can generate cost efficiencies by. By including the cost of investment in distribution and transportation costs in mind that in 2020, a third scenario could save Rp $127,229,422,000$,-per year than it is without building a packing plant $\mathrm{Rp} 1,002,443,597,600$ to $\operatorname{Rp} 850,446,425,600$.
\end{abstract}

Keywords: Packing Plant, Distribution, Transportation, cement, Transshipment.

\begin{abstract}
Abstrak: Sebagai produsen semen terbesar di Indonesia, PT Semen Gresik Group memiliki jaringan distribusi yang tersebar dari ujung Barat sampai ujung Timur Indonesia dan mendominasi pangsa pasar semen nasional sekitar 45\%. Untuk mendukung kecepatan distribusi ke seluruh pelosok nusantara, langkah strategis yang dilakukan adalah membangun pabrik pengantongan (Packing Plant) di area distribusi. Hasil analisa tahunan pada perusahaan, memindahkan Packing plant mendekati area distribusi dapat menjadi solusi efisiensi biaya transportasi hingga 43\% dibandingkan dengan keadaan sebelum memindahkan packing plant ke lokasi distribusi. Dan selanjutnya akan merupakan rencana strategis jangka panjang perusahaan. Pada penelitian ini akan dilakukan optimasi alokasi jaringan distribusi semen di pulau Kalimantan. Perancangan alokasi jaringan distribusi menggunakan model transshipment yaitu pengembangan dari model transportasi pada linear programming dengan bantuan software QM for Windows. Output yang diharapkan adalah terbentuknya jaringan distribusi yang optimal dengan total cost yang minimum. Untuk mengetahui efisiensi biaya dengan adanya packing plant, model optimasi yang
\end{abstract}


dibuat akan dilakukan running komputasi sebanyak empat kali. Terdapat empat skenario yang digunakan yaitu tanpa memindahkan packing plant, dengan adanya packing plant di Banjarmasin, dengan packing plant di Banjarmasin dan Pontianak, serta adanya packing plant di Banjarmasin, Pontianak dan Samarinda. Dari hasil keempat skenario tersebut diketahui bahwa dengan adanya packing plant dapat menghasilkan efisiensi biaya sebesar. Dengan memasukkan biaya investasi pada biaya distribusi dan transportasi diketahui bahwa pada tahun 2020, skenario ketiga dapat menghemat Rp 127,229,422,000,- per tahun dari apabila tanpa membangun packing plant Rp 1,002,443,597,600 menjadi Rp $850,446,425,600$.

Kata Kunci: Packing Plant, Distribusi, Transportasi, semen, Transshipment.

\section{PENDAHULUAN}

PT Semen Gresik (Persero) Group, atau sekarang berubah menjadi Semen Indonesia adalah produsen semen terbesar di Indonesia yang memiliki tiga anak perusahaan, yaitu PT Semen Gresik, PT Semen Padang dan PT Semen Tonasa. Berdasarkan laporan tahunan 2011, perseroan ini masih mendominasi pangsa pasar semen nasional sebesar 39.78\% di akhir 2012. Secara keseluruhan, total volume penjualan Perseroan tahun 2011 termasuk ekspor mencapai 19,7 juta ton. (Semen Gresik Group, 2011)

Semen Gresik termasuk dalam karateristik pasar oligopolistik natural yaitu pasar dikuasai oleh beberapa pemain perusahaan, namun tidak ada pembatasan kepada siapapun oleh pemerintah untuk siapa saja yang ingin membangun industri semen. Peningkatan kapasitas produksi sebesar 5,3\% di tahun 2011 yaitu menjadi 20 juta ton per tahun, akselerasi tingkat pembangunan konstruksi dan infrastruktur $10,5 \%$ serta meningkatnya pertumbuhan ekonomi masyarakat sebesar 6-6,5\% per tahun membuat perusahaan harus meningkatkan upaya memperluas pasar. (Semen Gresik Group, 2011).

Hal yang paling berpengaruh dalam perluasan dan pemeliharaan pasar yaitu kapasitas dan distribusi. Kapasitas produksi perusahaan harus dapat menyesuaikan dengan perkembangan pasar yang ada. Apabila kapasitas produksi lebih kecil daripada pertumbuhan pasar, maka banyak permintaan yang tidak dapat terpenuhi. Kapasitas terpenuhi namun tidak dilengkapi dengan fasilitas pengiriman yang memadai akan percuma karena barang sulit mencapai konsumen. Pada kenyataannya, biaya distribusi menjadi komponen biaya terbesar dari beban usaha yaitu sebesar Rp923,0 miliar atau 39,8\% dari total beban usaha di PT Semen Indonesia. (Departemen riset dan pemasaran PT Semen Gresik, 2012). Oleh karenanya dibutuhkan suatu alokasi jaringan distribusi yang optimal untuk mengurangi beban usaha perusahaan sehingga meningkatkan pendapatan perusahaan.

Dari Gambar 1 berikut ini, terlihat peningkatan presentasi total kebutuhan semen per tahun di luar pulau Jawa. Untuk mendukung peningkatan kapasitas produksi, Semen Gresik merencanakan pengembangan pasar luar Jawa. Dilihat pertumbuhan demand per tahunnya, Kalimantan memiliki nilai pertumbuhan demand yang lebih besar dibanding propinsi lainnya sampai dengan tahun 2012. Oleh karena itu Kalimantan memiliki potensi dijadikan tempat untuk pengembangan pasar.

Pendistribusian Semen Gresik saat ini untuk luar Jawa adalah melalui direct shipping yaitu semen dikirim dalam bentuk zak dari pabrik di Tuban melalui kapal barang (bag vessel) menuju pelabuhan umum di area distribusi. Kemudian dimuat dalam truk 
barang dengan kapasitas kecil untuk dikirimkan ke seluruh area, begitu juga dengan alur transportasi ke Kalimantan.

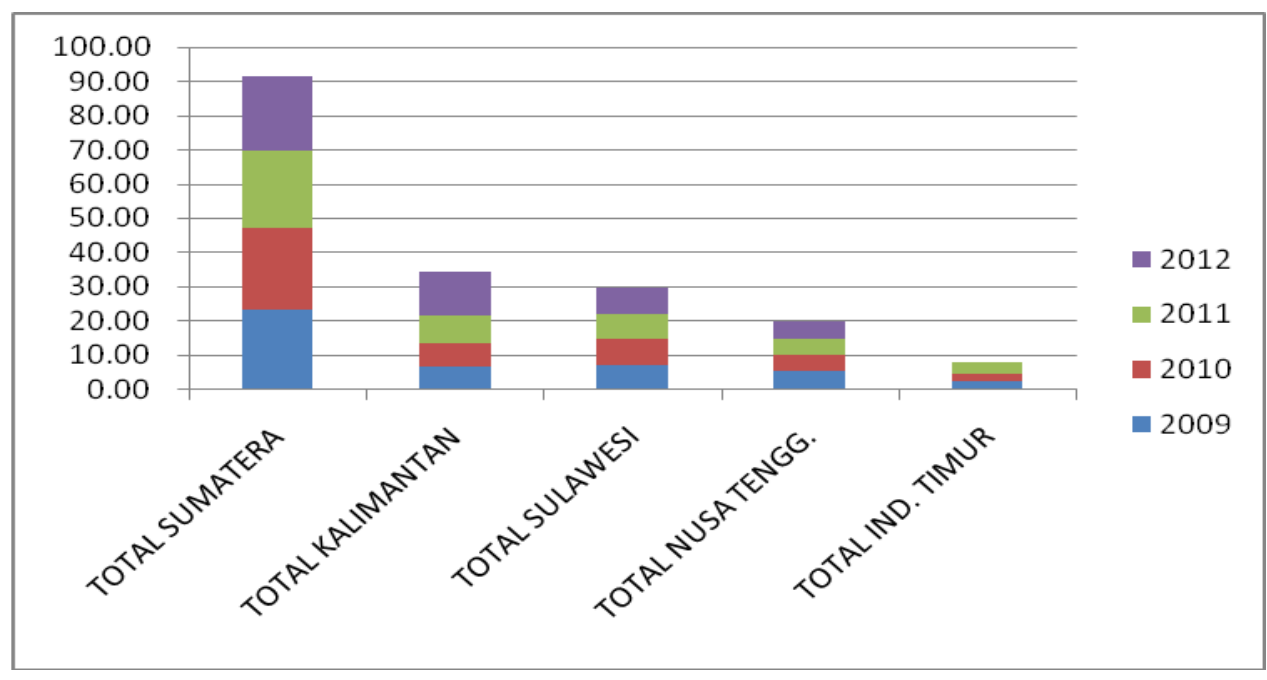

Gambar 1. Grafik Demand Nasional Luar Jawa tahun 2009-2012 (Asosiasi Semen Indonesia, 2011).

Semen Gresik memiliki dua belas distributor yang mendistribusikan ke seluruh area di pulau Kalimantan dengan total 28 lokasi gudang distributor yang tersebar di 16 kabupaten di Kalimantan. Dengan sistem transportasi seperti demikian, Semen Gresik mengalami Kendala yang dihadapi yaitu: (1) Kapasitas kirim yang rendah karena dikirim dalam bentuk bag dengan armada bag vessel; (2) Kerusakan kemasan di jalan akibat loading dan unloading kapal sehingga memerlukan kantong yang kuat dengan harga yang lebih tinggi;(3) Demoritas kapal akibat bongkar muat ke truk kecil memakan waktu yang cukup lama di pelabuhan. (Departemen Transportasi PT Semen gresik, 2012)

Dari data yang didapat, distribusi melalui angkutan laut terkendala disaat memuat dan membongkar barang yang masih dilakukan secara manual dan sangat tergantung pada kesiapan armada truk. (Semen Gresik, 2012). Masalah pendistribusian produk itu sendiri berkaitan langsung dengan masalah_transportasi yang merupakan salah satu masalah serius yang sering dihadapi karena tidak adanya koordinasi dalam pengiriman barang, sehingga memungkinkan terjadinya pembengkakan biaya pengiriman.

Untuk mengatasi permasalahan dan mendukung kecepatan distribusi ke seluruh pelosok nusantara dan meningkatkan efisiensi biaya dan jaringan distribusi, langkah strategis yang dilakukan adalah dengan membangun packing plant di beberapa lokasi strategis.

Packing Plant adalah sebuah peralatan penyimpanan semen lengkap dengan sistem bongkar muat yang efektif dan efisien yang didesain dengan minimum kapasitas 300.000 ton per tahun. Peralatan ini dilengkapi silo dengan daya tampung semen 3000 - 3500 Ton dengan kapasitas release bag minimal 80 Ton/jam atau 1680 ton/hari, pencatat timbangan masing-masing di Mesin Packaging (Roto Packer,) dan Truck Scale yang ditera oleh Balai Pengelolaan Meteorologi propinsi. 
PT Semen Gresik Group memiliki 15 packing plant yang tersebar di seluruh Indonesia. Pabrik pengantongan tersebut dioperasikan oleh PT Semen Gresik dan dua anak perusahaan nya PT Semen Tonasa dan PT Semen Padang. Tiga diantaranya dikelola langsung oleh Semen Gresik yaitu Ciwandan, Banyuwangi dan Sorong, Papua. Sebagai rencana jangka panjang, PT Semen Gresik (persero) mentargetkan akan membangun packing plant yang dikelola langsung oleh pihak PT Semen Gresik, salah satunya adalah di pulau Kalimantan, yang diharapkan dapat mengakomodir peningkatan demand dan kapasitas produksi dengan jaringan distribusi yang baik dan efisien serta dapat menurunkan biaya distribusi semen. (Semen Gresik, 2012)

Ditargetkan pada akhir tahun 2013 PT Semen Gresik merencanakan pembangunan packing plant di Banjarmasin, Kalimantan Selatan, dan pada perencanaan selanjutnya direncanakan pembangunan di Samarinda, Kalimantan Timur dan Pontianak, Kalimantan Barat. (Semen Gresik, 2012).

Dalam menentukan efisiensi biaya distribusi, alternatif lokasi pembangunan packing plant dan volume distribusi ke masing-masing wilayah perlu adanya suatu kajian dan analisis. Analisis dapat dilakukan dengan memodelkan terlebih dahulu alur distribusi lengkap dengan biaya dan volume kirim di masing-masing tujuan distribusi. Diharapkan hasil analisa tersebut dapat digunakan untuk membuat alternatif pilihan keputusan untuk menjalankan rencana jangka panjang pembangunan packing plant ditinjau dari segi biaya, lokasi, kapasitas maupun volume pengiriman.

Dengan adanya pabrik pengantongan maka keuntungan yang didapat adalah antara lain: (1) Kemampuan memenuhi semen dalam kemasan bag dan curah; (2) Kemasan semen bag lebih bersih bila dibanding dengan pengiriman langsung semen bag dari pabrik dengaan menggunakan kapal general cargo karena tidak banyak handling sehingga semen pecah bisa ditekan seminimum mungkin; (3) Adanya jaminan supply karena jadwal kapal yang lebih pasti dan cepat bongkar dengan adanya dermaga milik perusahaan sendiri; (4) Meningkatkan market share, karena ketersediaan barang terjamin.

Perumusan masalah yang perlu dikaji dan dianalisis adalah: (1) Bagaimana mengoptimasi jaringan distribusi yang optimal dari pabrik ke packing plant dan dari packing plant ke gudang distributor; (2) Bagaimana membandingkan efisiensi biaya distribusi dan transportasi setelah adanya packing plant; (3) Bagaimana menetukan kapasitas pembangunan unit packing plant di masing-masing lokasi tujuan distribusi.

Penelitian ini bertujuan untuk: (1) Melakukan optimasi alokasi jaringan distribusi semen ke Kalimantan menggunakan model Transshipment sebagai metode pengambilan keputusan; (2) Membandingkan efisiensi biaya distribusi dan transportasi sebelum dan setelah adanya packing plant di Banjarmasin, Samarinda dan Pontianak; (3) Menentukan alternatif alur distribusi paling efektif untuk distribusi semen dalam bentuk packing ke Kalimantan;(4) Menentukan Kapasitas pembangunan unit pabrik pengantongan semen di area tujuan distribusi untuk meningkatkan pasar di Kalimantan.

\section{KAJIAN TEORI}

Berdasarkan hasil diskusi dengan beberapa pihak terkait dari PT semen Gresik dan studi lapangan, diketahui bahwa dimulai tahun 2013 semen gresik akan memindahkan pabrik pengantongan ke beberapa wilayah di luar pulau jawa khususnya Kalimantan sebagai perpanjangan dari pabrik semen untuk memasarkan semen.Hal ini dikarenakan pertimbangan berikut ini: (1) Alur distribusi saat ini kurang cepat men-supply semen; (2) 
Diharapkan dengan memindahkan packing plant dapat memperluas pasar karena barang cepat tersedia dan harga lebih murah; (3) Semen Gresik menetapkan tiga lokasi yang dianggap strategis untuk dibangun packing plant yaitu Banjarmasin, Samarinda dan Pontianak.

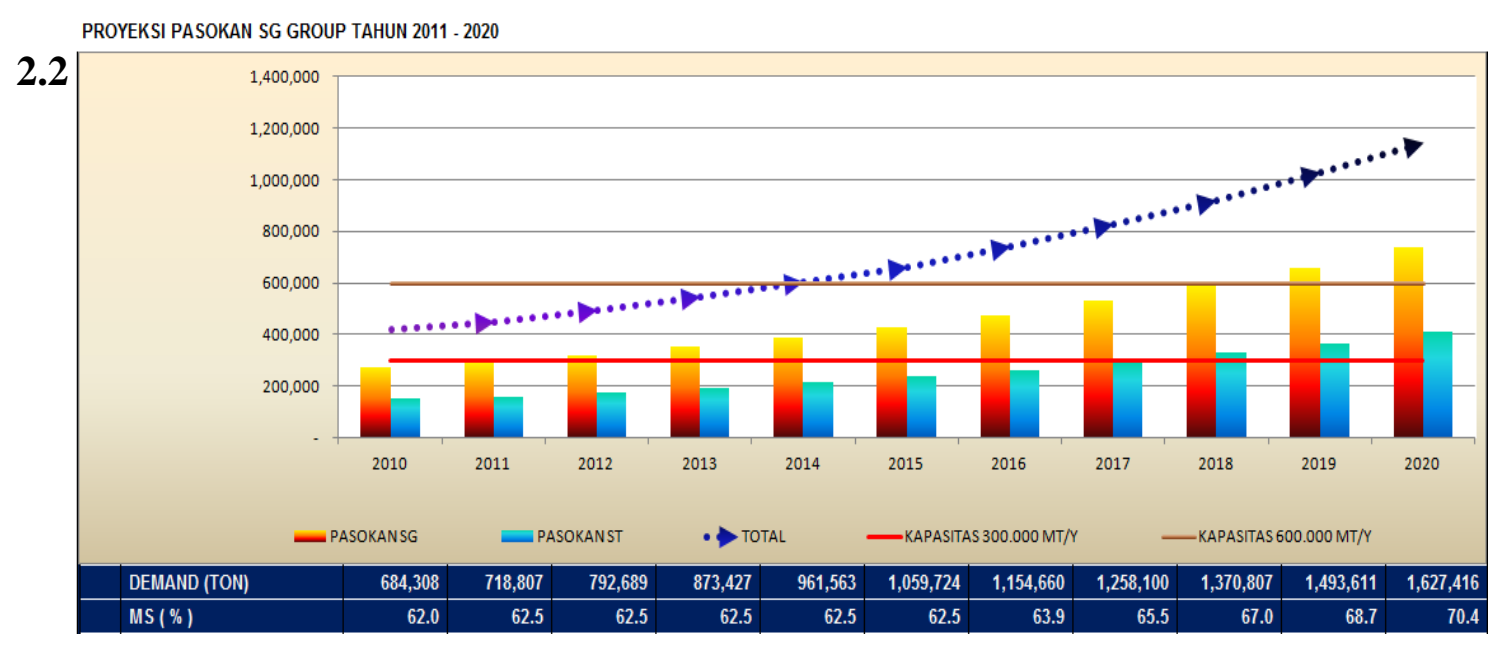

Gambar 2. Proyeksi pasokan Semen Gresik Group Tahun 2011-2020. (Semen Gresik, 2012)

Dari Gambar 2 di atas, Semen Gresik memprediksi akan kenaikan demand yang signifikan sampai dengan tahun 2020 mendatang. Kenaikan permintaan semen tersebut berbanding lurus dengan kebutuhan alur transportasi yang baik. Oleh sebab itu, sebagai rencana jangka panjang, Semen Gresik merencanakan pembangunan packing plant sebagai perpanjangan tangan pabrik semen di area-area strategis termasuk di Kalimantan selatan, Kalimantan timur dan Kalimantan barat.

Bustani (2005) menyatakan bahwa salah satu dari beberapa definisi riset operasional adalah metoda ilmiah yang memungkinkan para manajer atau praktisi bisnis untuk mengambil keputusan mengenai aktivitas bisnis.

Riset operasi juga didefinisikan sebagai peralatan manajemen yang berupa gabungan matematika dan logika yang digunakan untuk pemecahan masalah dalam kehidupan sehari-hari, sehingga permasalahan tersebut diselesaikan secara optimal.

Program Linear. Program linear (linear programming) adalah beberapa metode riset operasi yang dapat digunakan untuk memecahkan permasalahan dengan sumber-sumber daya terbatas, dengan tujuan untuk memaksimalkan keuntungan atau meminimalkan biaya. Pada perumusan program linier harus dipahami tujuan penyelesaian masalah dan penyebab masalah, sehingga program linier mempunyai 2 (dua) macam fungsi, yaitu: (1) Fungsi tujuan (objective function), adalah fungsi yang menggambarkan tujuan yang akan dimaksimalkan atau diminimalkan; (2) Fungsi batasan atau juga disebut fungsi kendala, adalah merupakan batasan-batasan sumber daya yang disajikan secara matematis.

Secara umum model program linier terdiri dari $n$ variabel keputusan dengan simbol $X i$ indek $i$ berjalan dari 1 sampai $n$, dan $m$ kendala dinyatakan dengan $b j$ indek $j$ berjalan dari 
1 sampai $m$, maka secara umum modelnya dalam bentuk standar dapat dituliskan sebagai berikut:

$$
\begin{aligned}
& \text { Maksimalkan } \quad \mathrm{Z}=\mathrm{C}_{1} \mathrm{X}_{1}+\mathrm{C}_{2} \mathrm{X}_{2}+\ldots+\mathrm{C}_{\mathrm{n}} \mathrm{X}_{\mathrm{n}} \\
& \text { Kendala: } \quad \mathrm{A}_{11} \mathrm{X}_{1}+\mathrm{A}_{12} \mathrm{X}_{2}+\ldots+\mathrm{A}_{1 \mathrm{n}} \mathrm{X}_{\mathrm{n}} \leq \mathrm{B}_{1} \\
& A_{21} X_{1}+A_{22} X_{2}+\ldots+A_{2 n} X_{n} \leq B_{2 .} . \\
& A_{m 1} X_{1}+A_{m 2} X_{2}+\ldots+A_{m n} X_{n} \leq B_{m}
\end{aligned}
$$

$\mathrm{i}=1,2,3, \ldots . \mathrm{n}$ dan $\mathrm{j}=1,2,3, \ldots \mathrm{m} ; \mathrm{Z}=$ nilai total keuntungan; $\mathrm{X} i=$ Tingkat kegiatan; $\mathrm{C} i=$ penambahan keuntungan bila $\mathrm{X} i$ naik 1 unit; bi = sumber daya $i$ yang tersedia untuk dialokasikan pada semua kegiatan; Aij = resource $i$ yang digunakan untuk kegiatan $j$

Pada perumusan tersebut diatas harus dipenuhi aturan sebagai berikut: (1) Formulasi program linier hanya mempunyai satu fungsi tujuan yaitu maksimalisasi atau minimalisasi; (2) Fungsi tujuan untuk laba dan pendapatan adalah maksimalisasi, sedangkan fungsi tujuan waktu dan biaya adalah minimalisasi; (3) Untuk fungsi tujuan maksimalisasi, fungsi kendala harus mempunyai minimal satu fungsi yang mempunyai tanda batasan lebih kecil sama dengan $(\leq)$ atau sama dengan $(=)$. Apabila tidak maka solusinya adalah unbounded solution; (4) Untuk fungsi tujuan minimalisasi, fungsi kendala harus mempunyai minimal satu fungsi yang mempunyai tanda batasan lebih besar sama dengan $(\geq)$ atau sama dengan $(=)$. Apabila tidak maka solusinya adalah unbounded solution; (5) Daerah solusi harus berada pada satu daerah dan apabila terdapat pada dua daerah solusi atau lebih, maka persoalan program linier tersebut tidak dapat diselesaikan (infeasible solution atau inconsistent).

Defisini dan Aplikasi Model Transportasi. Masalah transportasi berhubungan dengan distribusi suatu produk tunggal dari beberapa sumber, dengan penawaran terbatas, menuju beberapa tujuan, dengan permintaan tertentu, pada biaya transport minimum. Karena hanya ada satu macam barang, suatu tempat dapat memenuhi permintaannya dari satu sumber atau lebih.

Asumsi dasar model ini adalah bahwa biaya transport pada suatu rute tertentu proporsional dengan banyaknya unit yang dikirimkan. Definisi unit yang dikirimkan sangat tergantung pada jenis produk yang diangkut, yang penting satuan penawaran dan permintaan akan barang yang diangkut harus konsisten.

Sebuah model transportasi dapat dibayangkan seperti contoh berikut. Misalnya suatu produk yang dihasilkan pada tiga pabrik harus didistribusikan ke tiga gudang seperti ditunjukan pada Gambar 2 Setiap pabrik memiliki kapasitas produksi tertentu dan setiap gudang memiliki jumlah permintaan tertentu terhadap produk itu. Dengan diketahuinya biaya transport per unit dari masing-masing pabrik yang harus dikirim dari masing-masing pabrik ke masing-masing gudang dengan tujuan meminimumkan biaya transport. (Taylor III, 2004) Pabrik Volume yang diangkut (Xij)Gudang.

Persyaratan masalah ini adalah bahwa permintaan pada setiap gudang harus dipenuhi tanpa melebihi kapasitas produksi pada setiap pabrik. Masalah ini dapat dirumuskan sebagai program linier seperti berikut:

Misalnya Xij : banyaknya unit barang yang dikirim dari pabrik ke $-i(i=1,2,3, \ldots . . \mathrm{m})$ menuju ke gudang ke $-j$, sehingga rumus umum masalah transportasi biaya termurah dengan $m$ daerah asal dan $n$ gudang adalah:

Minimumkan biaya transport total $=\sum_{i=1}^{m} \sum_{j=1}^{n} \boldsymbol{C i j} \cdot \boldsymbol{X} \boldsymbol{i} \boldsymbol{j}$ 


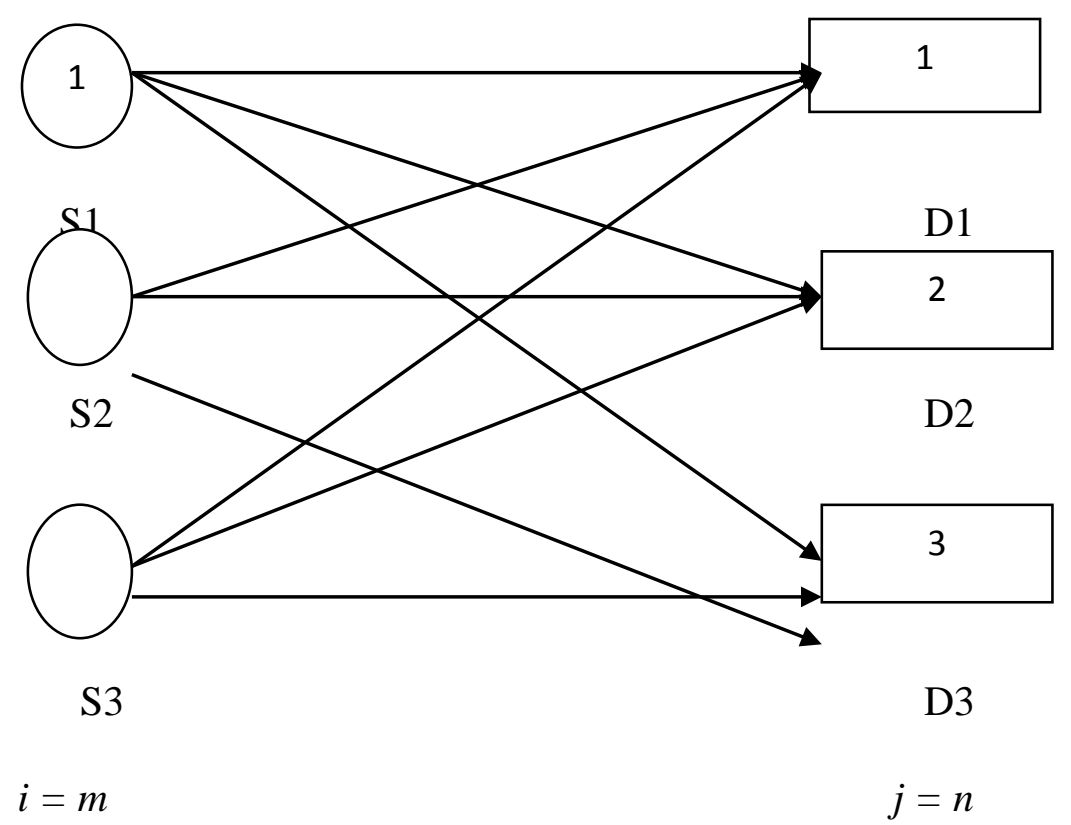

Gambar 3. Model Jaringan Transportasi.(Taylor III, 2004)

Kendala model menunjukkan jumlah yang dapat ditawarkan oleh masing-masing pabrik dan jumlah yang diminta pada setiap pasar sebagai jumlah dari alternatif-alternatif pengiriman secara individu (tiap rute). Kendalanya berupa persamaan karena masalahnya simbang yaitu semua barang yang ditawarkan akan didistribusikan dan semua permintaan akan dipenuhi.

Dengan syarat: $\sum_{j=1}^{n} X i j=S j$ (penawaran, $\left.\mathrm{i}=1,2,3, \ldots . \mathrm{m}\right)$

$\sum_{i=1}^{m} X i j=D j($ permintaan, $\mathrm{j}=1,2,3, \ldots \ldots \mathrm{n})$

Semua $\mathrm{X}_{\mathrm{ij}}>0$

Dalam program linier untuk model jaringan transportasi ada 2 masalah yang harus diperhatikan adalah: (1) Masalah Transportasi Seimbang. Yaitu kondisi dimana supply atau penawaran sama dengan demand atau permintaan; (2) Masalah Transportasi Tak Seimbang. Yaitu kondisi dimana supply/penawaran lebih besar atau lebih kecil dari demand/permintaan

Model Transshipment. Masalah transportasi memungkinkan pengiriman hanya langsung dari titik suplai ke titik permintaan. Dalam banyak situasi, pengiriman yang diizinkan antara titik suplai atau antara titik permintaan. Akan tetapi di beberapa kasus transportasi pengiriman barang tidak langsung ke titik permintaan melainkan melalui titik transit terlebih dahulu (disebut titik transshipment) dimana barang dapat kapalkan dalam perjalanan dari titik suplai ke titik permintaan. Solusi optimal untuk masalah transshipment dapat ditemukan dengan memecahkan masalah transportasi.

Definisi lain menyatakan, Transshipment adalah pengiriman barang tidak langsung dari sumber ke tujuan tetapi disalurkan melalui Transshipment Point (T). Titik 
Transshipment dapat merupakan titik transit murni. Namun, juga dapat merangkap menjadi titik sumber ( $\mathrm{T}(\mathrm{S})$ ) maupun sebagai titik tujuan (destination) $\mathrm{T}$ (D).

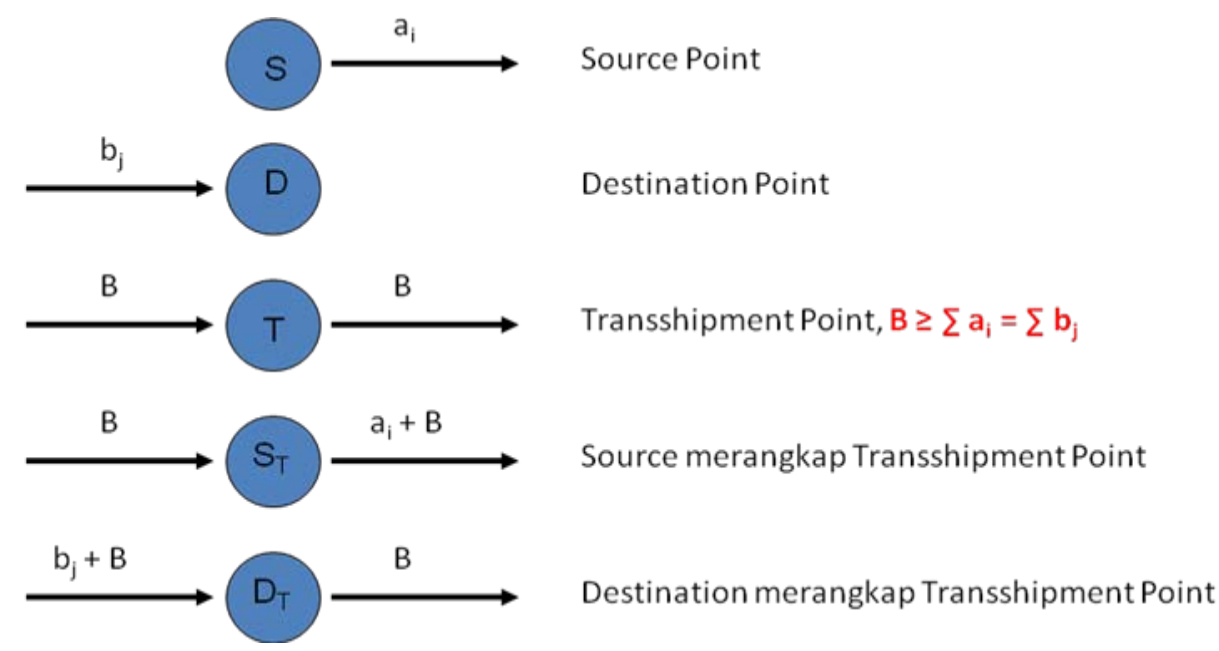

Gambar 4. MacamTitik Transshipment.

Sumber: (Taylor III, 2004)

Packing Plant. Dalam industri semen, pada proses produksi akan diakhiri dengan proses pengepakan yang dilakukan di packing plant. Umumnya packing plant terletak di dalam pabrik. Berada pada rangkaian mesin produksi di bagian akhir. Namun, pada PT Semen Gresik Group, dengan tujuan untuk mempercepat dan efisiensi distribusi semen maka packing plant diletakkan di lokasi distribusi sebagai perpanjangan tangan dari pabrik. Packing Plant yang dimaksud disini adalah sebuah peralatan penyimpanan semen lengkap dengan sistem unloading dan loading yang efektif dan efisien. Peralatan ini dilengkapi Silo dengan daya tampung semen minimal 3000 Ton, bangunan unloading dan distribusi, bangunan pengepakan dengan kapasitas release bag minimal 80 Ton/jam atau 1680/hari, jembatan timbang, dermaga dan fasilitas kantor dan post jaga. Fungsi dari packing plant ini sendiri selain untuk menyiapkan semen dalam kemasan bag dan curah sebelum dilakukan pendistribusian ke area pasar di luar pulau. Sampai dengan saat ini PT Semen Gresik group telah mengoperasikan 15 lokasi Packing plant yang tersebar di seluruh nusantara. Pada 2015 PT Semen Gresik Group menargetkan akan memiliki total 17 packing plant yang telah beroperasi. PT Semen Gresik, mengelola 3 lokasi packing plant yaitu di Ciwandan, Banyuwangi dan Sorong.

Mulai 2013 Semen Gresik merencanakan pembangunan packing plant di Kalimantan selatan dan diikuti dengan wilayah Kalimantan timur dan Kalimantan barat yaitu Banjarmasin, Samarinda dan Pontianak. untuk men-supply seluruh kabupaten di Kalimantan, berikut peta sebaran packing plant milik Semen Gresik Group. (Semen Gresik, 2012)

Dari hasil wawancara dengan divisi Pengembangan dan Pemasaran PT Semen Gresik, keberadaan pabrik pengantongan sangat diperlukan untuk menjamin kelancaran pasokan pasar di luar pulau Jawa. Untuk itu bagi semen gresik group investasi pabrik pengantongan bersifat mandatory. Dengan adanya pabrik pengantongan maka keuntungan yang didapat adalah antara lain: (1) Kemampuan memenuhi semen dalam kemasan bag 
dan curah; (2) Kemasan semen bag lebih bersih bila dibanding dengan pengiriman langsung semen bag dari pabrik dengaan menggunakan kapal general cargo karena tidak banyak handling sehingga semen pecah bisa ditekan seminimum mungkin; (3) Adanya jaminan supply karena jadwal kapal yang lebih pasti dan cepat bongkar dengan adanya dermaga milik perusahaan sendiri; (4) Meningkatkan market share, karena ketersediaan barang terjamin.

\section{METODE}

Jenis Penelitian. Penelitian ini termasuk pada jenis penelitian kuantitatif yaitu: Jenis Data yang Digunakan (1) Data primer : wawancara; (2) Data sekunder: laporan tahunan PT Semen Gresik, Data Realisasi penjualan semen se Indonesia di PT Semen Gresik, Data Ongkos Angkut Semen Gresik

Alur Metodologi Penelitian. Proses penelitian merupakan proses terstruktur sehingga diperlukan aturan dan langkah-langkah tertentu untuk melaksanakannya. Dengan demikian maka proses penelitian dapat dipahami dan diikuti pihak lain secara sistematis. Penelitian dilakukan menggunakan metode Transshipment pada linier programming. Adapun langkah-langkah yang akan dilakukan untuk mencapai tujuan dalam penelitian ini adalah sebagai berikut.

Pengumpulan Data. Data-data yang dibutuhkan dalam penelitian dengan judul Studi Penggunaan Packing Plant pada Distribusi Semen di PT Semen Gresik adalah meliputi: (1) Data gudang distributor Semen Gresik yang terdapat di Kalimantan; (2) Data permintaan semen di tiap wilayah gudang distribusi Semen Gresik di Kalimantan; (3) Data alur distribusi Semen Gresik yang dilakukan saat ini ke Kalimantan; (4) Data biaya-biaya yang terdapat dalam alur distribusi saat ini dan jika menggunakan packing plant sebagai titik transit.

Data didalam penelitian ini digunakan untuk menentukan alternatif pembangunan packing plant sebagai titik transit distribusi semen ke Kalimantan dengan mempertimbangkan minimum biaya distribusi dan kecepatan pengiriman. Lokasi packing plant telah ditetapkan oleh pihak Perusahaan didasari pertimbangan banyaknya permintaan di wilayah tersebut, yaitu Banjarmasin, Samarinda dan Pontianak. Kalimantan memiliki potensi dijadikan tempat untuk pengembangan pasar, karena pertumbuhan pasar tiap tahunnya selalu meningkat cukup signifikan.

Tabel 1. Total Realisasi Penjualan Semen Gresik di Kalimantan per tahun mulai 2009 sampai dengan 2012.

\begin{tabular}{lccc}
\hline \multicolumn{4}{l}{ Realisasi Penjualan Semen Gresik di Kalimantan } \\
\hline Th 2009 & Th 2010 & Th 2011 & Th 2012 \\
680,438 & 852,091 & 864,978 & 935,715 \\
\hline
\end{tabular}

dalam Ton 
Analisa Data. Pada tahap ini dilakukan pengolahan data-data yang didapat dari data operasional dan data berupa asumsi yang ditetapkan. Adapun data-data yang perlu disiapkan yaitu sebagai berikut: (1) Penetapan jumlah demand di - n gudang distributor serta asumsi fluktuasi demand tiap tahunnya;(2) Perhitungan biaya operasional per pengiriman semen dari pabrik ke Packing plant ke-m; (3) Perhitungan biaya operasional per pengiriman semen dari packing plant ke- $m$ menuju ke- $n$ gudang distributor di Kalimantan; (4) Penetapan asumsi biaya per pengiriman ke- $n$ lokasi gudang distributor dari pabrik pengantongan jika pabrik pengantongan berada di lokasi - $m$; (4) Penetapan asumsi kapasitas kapal, biaya sewa kapal untuk setiap aktifitas kapal meliputi loading, sailing full, unloading, sailing empty load dan anchorage; (5) Selanjutnya data-data tersebut dilakukan optimasi dengan menggunakan software QM for Windows dan hasil dari proses ini adalah didapatkan alternative jalur yang efisien dengan biaya operasional yang murah serta penetapan lokasi dan kapasitas pembangunan packing plant yang efektif.

Tabel 1 Total Realisasi Penjualan Semen Gresik di Kalimantan per tahun mulai 2009 sampai dengan 2012. (Semen Gresik, 2012). Seperti yang telah dijelaskan pada pendahuluan, distribusi Semen Gresik dikirim dalam bentuk bag dari pelabuhan di Tuban melalui kapal barang (bag vessel) menuju pelabuhan umum di area distribusi. Kemudian dimuat dalam truk barang dengan kapasitas kecil antara 200-300 bag untuk dikirimkan ke seluruh kabupaten-kabupaten di Kalimantan.

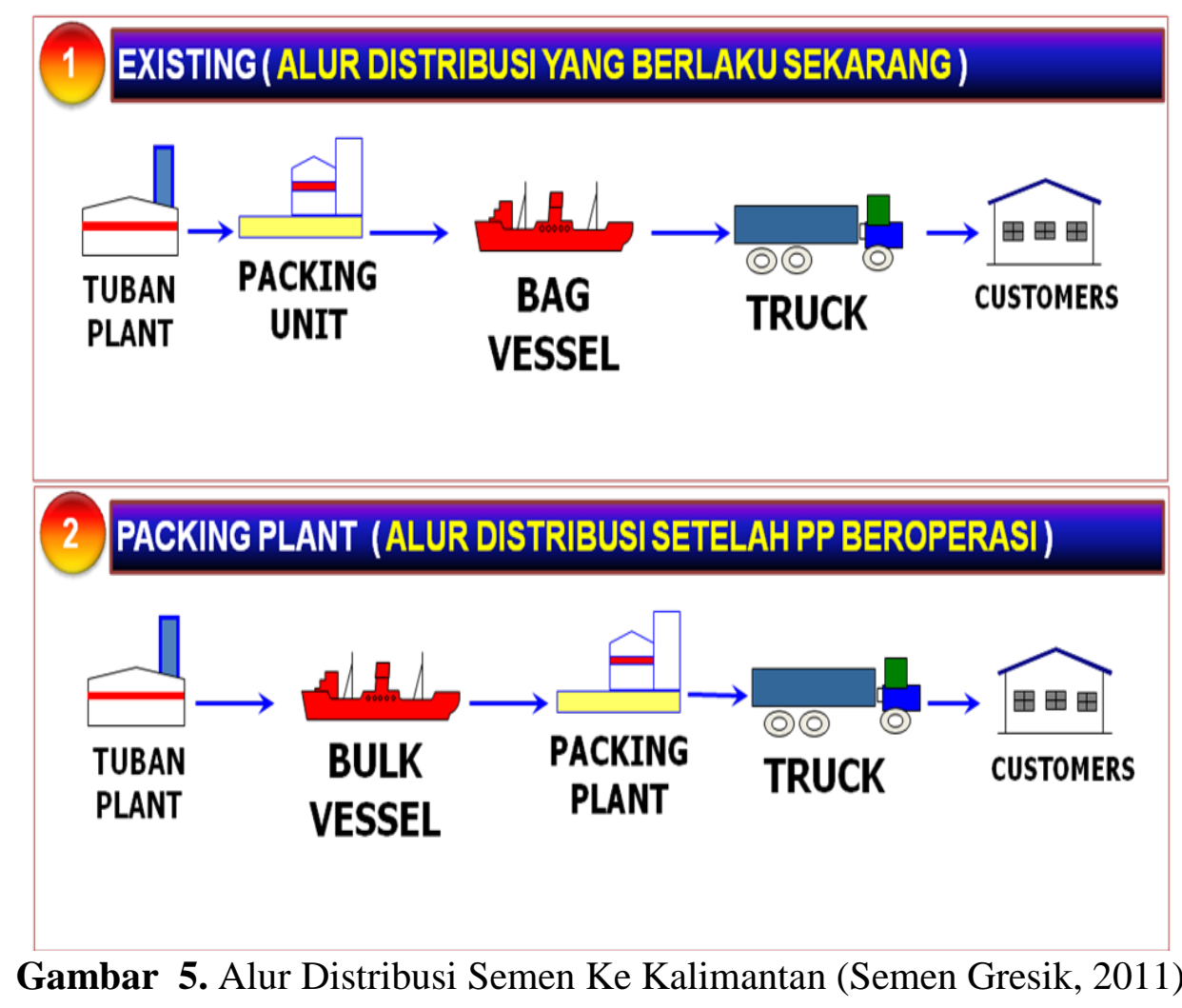

Semen gresik memiliki dua belas distributor yang mencakup seluruh area dengan total 28 lokasi gudang distributor yang tersebar di 16 kabupaten di Kalimantan.

Data demand gudang distributor wilayah Kalimantan. Data demand gudang distributor di Kalimantan diperoleh dari rata-rata data realisasi penjualan semen dari tahun 
2009 sampai dengan 2012. Tabel dibawah ini menyajikan data rata-rata demand masingmasing wilayah.

Data Biaya distribusi. Berikut menjelaskan data biaya-biaya yang terdapat dalam alir distribusi semen ke Kalimantan dengan metode distribusi saat ini dan dengan alternatif menggunakan packing plant sebagai titik transit.

Tabel 2. Data demand gudang distributor wilayah Kalimantan (dalam ton)

\begin{tabular}{|c|c|c|c|c|c|}
\hline \multicolumn{2}{|c|}{ Area Distribusi } & \multirow{2}{*}{$\begin{array}{r}2009 \\
28,152\end{array}$} & \multirow{2}{*}{$\begin{array}{r}2010 \\
37,448\end{array}$} & \multirow{2}{*}{$\begin{array}{r}2011 \\
48,325\end{array}$} & \multirow{2}{*}{$\begin{array}{r}2012 \\
55,090\end{array}$} \\
\hline Kalimantan & Ketapang & & & & \\
\hline & Pontianak & 31,139 & 41,421 & 53,451 & 104,897 \\
\hline \multirow{3}{*}{$\begin{array}{l}\text { Kalimantan } \\
\text { Selatan }\end{array}$} & Banjar & 80,421 & 98,162 & 94,275 & 106,768 \\
\hline & Banjarmasin & 165,824 & 202,403 & 194,390 & 220,149 \\
\hline & $\begin{array}{l}\text { Kotawaringin } \\
\text { Barat }\end{array}$ & 584 & 713 & 684 & 775 \\
\hline \multirow[t]{5}{*}{$\begin{array}{l}\text { Kalimantan } \\
\text { Tengah }\end{array}$} & $\begin{array}{l}\text { Kotawaringin } \\
\text { Timur }\end{array}$ & 64,936 & 81,624 & 85,373 & 84,882 \\
\hline & Palangkaraya & 112,667 & 141,621 & 148,127 & 147,274 \\
\hline & Seruyan & 2,607 & 3,277 & 3,428 & 3,408 \\
\hline & Teluk Kumai & 81,711 & 102,710 & 107,428 & 106,810 \\
\hline & Bukit Pinang & 650 & 817 & 855 & 850 \\
\hline \multirow{6}{*}{$\begin{array}{l}\text { Kalimantan } \\
\text { Timur }\end{array}$} & Balikpapan & 36,543 & 46,403 & 42,068 & 34,277 \\
\hline & Berau & 6,083 & 7,725 & 7,003 & 5,706 \\
\hline & Bulungan & 15,263 & 19,380 & 17,570 & 14,316 \\
\hline & Nunukan & 12,988 & 16,493 & 14,952 & 12,183 \\
\hline & Samarinda & 35,645 & 45,261 & 41,034 & 33,434 \\
\hline & Tarakan & 5,224 & 6,633 & 6,014 & 4,900 \\
\hline $\begin{array}{l}\text { Total } \\
\text { Kalimantan }\end{array}$ & & 680,438 & 852,091 & 864,978 & 935,715 \\
\hline
\end{tabular}

Data Biaya Distribusi saat ini. Berdasarkan hasil wawancara dan studi lapangan, saat ini Semen Gresik mengirimkan semen hanya dalam bentuk bag ke pulau Kalimantan. Biaya distribusi semen bag mulai keluar dari pabrik menuju ke pabrik pengantongan sampai dengan ke gudang distributor adalah sebagai berikut: (1) Ongkos angkut berupa biaya loading semen curah ke dalam pabrik pengantongan atau disebut ongkos pengiriman pabrik (OPP), biaya kirim dengan kapal barang franco dari pabrik Tuban; (2) Sewa kapal barang kapasitas 1000- 3000 ton; (3) Cycle time/Trip = 8 hari (loading 1 hari, unloading 4 hari, departure and return 3 hari); (4) Dalam pengiriman barang, semen dikategorikan barang pengganggu sehingga di bongkar paling akhir setelah barang bahan pokok lainnya; (5) Jika dikirim dalam bentuk bag, membutuhkan jenis bahan kantong yang kuat (woven) 
agar tidak mudah pecah dan rusak saat pengiriman. Sehingga biaya kantong menjadi tinggi.

Data Biaya distribusi setelah memindahkan Packing plant (PP). Jika Packing Plant dipindahkan mendekati lokasi distribusi yaitu Banjarmasin, Samarinda dan Pontianak, perhitungan ongkos angkut yaitu OPP ditambah dengan pengiriman menggunakan kapal ke PP di Kalimantan. Data biaya distribusi dengan alternatif PP berada di lokasi distribusi adalah OPP ditambah dengan biaya pengiriman kapal curah (freight), yang ditentukan berdasarkan pendekatan survey harga sewa kapal curah dari Tuban ke Kalimantan dan asumsi perhitungan jarak.

Tabel 3. Biaya distribusi Semen Gresik dari Tuban ke Kalimantan (Rp/ton)

\begin{tabular}{|c|c|c|c|c|c|}
\hline REA DIS & TRIBUSI & $\begin{array}{l}\text { BIAYA } \\
\text { KEMASAN }\end{array}$ & OPP & $\begin{array}{c}\text { Freight } \\
\text { Franco dari } \\
\text { Tuban }\end{array}$ & OPT \\
\hline $\begin{array}{l}\text { Area Kalimantan } \\
\text { Barat }\end{array}$ & Ketapang & 110,000 & 50,328 & 244,160 & 52,797 \\
\hline & PONTIANAK & 110,000 & 50,328 & 249,610 & 52,739 \\
\hline Area Kalimantan & Banjar Baru & 110,000 & 50,328 & 201,650 & 42,300 \\
\hline & BANJARMASIN & 110,000 & 50,328 & 201,105 & 44,348 \\
\hline & $\begin{array}{l}\text { KOTAWARINGI } \\
\text { N BARAT }\end{array}$ & 110,000 & 50,328 & 201,105 & 45,321 \\
\hline $\begin{array}{l}\text { Area Kalimantan } \\
\text { Tengah }\end{array}$ & $\begin{array}{l}\text { Kotawaringin } \\
\text { Timur/S }\end{array}$ & 110,000 & 50,328 & 188,900 & 58,900 \\
\hline & $\begin{array}{l}\text { PALANGKARA } \\
\text { YA }\end{array}$ & 110,000 & 50,328 & 215,820 & 119,410 \\
\hline & SERUYAN & 110,000 & 50,328 & 213,640 & 110,000 \\
\hline & TELUK KUMAI & 110,000 & 50,328 & 216,910 & 73,547 \\
\hline & BUKIT PINANG & 110,000 & 50,328 & 250,700 & 91,933 \\
\hline $\begin{array}{l}\text { Area Kalimantan } \\
\text { Timur }\end{array}$ & Balikpapan & 110,000 & 50,328 & 212,550 & 71,980 \\
\hline & BERAU & 110,000 & 50,328 & 212,500 & 57,807 \\
\hline & BULUNGAN & 110,000 & 50,328 & 272,500 & 57,807 \\
\hline & NUNUKAN & 110,000 & 50,328 & 305,200 & 61,420 \\
\hline & SAMARINDA & 110,000 & 50,328 & 250,700 & 56,000 \\
\hline & TARAKAN & 110,000 & 50,328 & 288,850 & 61,420 \\
\hline
\end{tabular}

Tabel 4.Ongkos Angkut semen ke Packing Plant (Rp/Ton)

\begin{tabular}{|c|c|c|c|c|}
\hline & & PP Banjarmasin & PP Samarinda & PP Pontianak \\
\hline & & B & $\mathrm{C}$ & $\mathrm{D}$ \\
\hline $\begin{array}{l}\text { Source } \\
\text { Tuban) }\end{array}$ & (Pabrik & 150,739 & 244,000 & 256,000 \\
\hline
\end{tabular}

Tabel perbandingan biaya distribusi. Dengan memindahkan packing plant ke lokasi maka angkutan yang digunakan yaitu dengan angkutan laut sebagai berikut: (1) Sewa 
Kapal General Cargo dengan Kapasitas @6.000 tons untuk angkutan semen curah. Bila menggunakan sewa kapal general cargo, maka akan diperoleh efisiensi yang lebih besar karena kapal general cargo lebih mudah didapat dengan sewa yang lebih murah; (2) Perjalanan Kapal (3.000 ton): cycle time/Trip = 5 hari (loading 1 hari, unloading 1 hari, departure and return 3 hari. Karena leadtime cepat, maka kapal bisa lebih sering kirim, sehingga barang tersedia di lokasi supply; (3) Harga kantong lebih murah, karena tidak resiko perjalanan laut; (4) Kekurangan: biaya investasi awal tinggi yaitu Rp 120.200.000.000,- per unit kapasitas 300.000 ton/tahun.

Tabel 5. Ongkos angkut ke gudang distribusi dari PP Banjarmasin, Samarinda dan Pontianak.

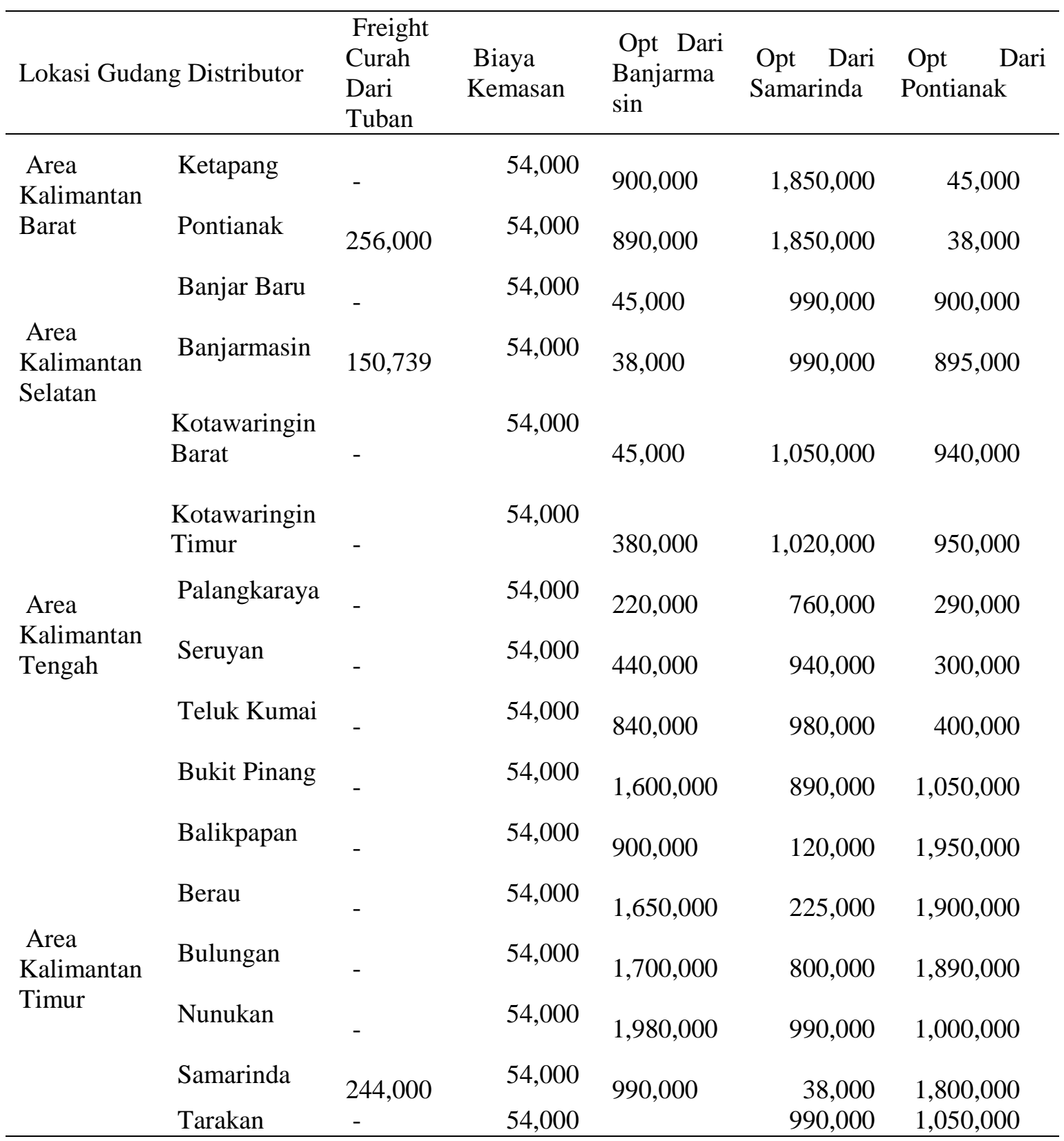


Model Penelitian. Seperti yang telah dijelaskan sebelumnya, distribusi semen saat ini di wilayah luar pulau Jawa dikirimkan langsung dari Tuban sebagai lokasi produksi PT Semen Gresik. Untuk tujuan melebarkan pasar, khususnya di Kalimantan, Semen Gresik dituntut untuk selalu menyediakan barang dengan harga dibawah competitor. Maka Semen Gresik membutuhkan jalur distribusi yang cepat dan efisien. Pembanguman packing plant di Kalimantan diprediksi dapat menjadi solusi yang tepat. Terdapat 3 lokasi yang ditetapkan oleh PT Semen Gresik sebagai lokasi Pabrik Pengantongan yaitu Banjarmasin di Kalimantan Selatan, Samarinda di Kalimantan Timur dan Pontianak di Kalimantan barat. Namun, perlu dikaji ulang lokasi mana yang paling tepat untuk didirikannya pabrik pengantongan serta apakah memang benar hal tersebut menjadi solusi tepat atau justru lebih efisien bila dikirim melalui Tuban.

Berdasarkan data-data yang telah dikumpulkan, dibangun model Transshipment untuk mencari alternatif alur distribusi dengan biaya paling minimum, efisien dan cepat dalam mengirimkan semen. Model yang dibangun sesuai data-data diatas adalah seperti dibawah ini dimana: $\mathrm{S}=$ Pabrik Semen Gresik di Tuban; $\mathrm{A}=$ Packing Plant Tuban; $\mathrm{B}=$ Packing Plant Banjarmasin; $\mathrm{C}=$ Packing Plant Samarinda; $\mathrm{D}=$ Packing Plant Pontianak $1,2,3, \ldots 16=$ Lokasi gudang distribusi; $\mathrm{D}_{1}, \mathrm{D}_{2}, \mathrm{D}_{3}, \ldots \mathrm{D} 16=$ demand dari masing-masing lokasi distribusi, dengan keterangan sebagai berikut:

Tabel 6. Area gudang distributor di Kalimantan.

\begin{tabular}{llll}
\hline simbol & Kota / Wilayah & simbol & Kota / Wilayah \\
\hline $\mathrm{D}_{1}$ & Tarakan & $\mathrm{D}_{9}$ & Seruyan \\
$\mathrm{D}_{2}$ & Samarinda & $\mathrm{D}_{10}$ & Palangkaraya \\
$\mathrm{D}_{3}$ & Nunukan & $\mathrm{D}_{11}$ & Kotawaringin Timur \\
$\mathrm{D}_{4}$ & Bulungan & $\mathrm{D}_{12}$ & Kotawaringin Barat \\
$\mathrm{D}_{5}$ & Berau & $\mathrm{D}_{13}$ & Banjarmasin \\
$\mathrm{D}_{6}$ & Balikpapan & $\mathrm{D}_{14}$ & Banjar \\
$\mathrm{D}_{7}$ & Bukit Pinang & $\mathrm{D}_{15}$ & Pontianak \\
$\mathrm{D}_{8}$ & Teluk Kumai & $\mathrm{D}_{16}$ & Ketapang \\
\hline
\end{tabular}

Seperti juga permasalahan pada model transportasi, model linier programming dibentuk dengan batasan supply dan demand. Batasan tersebut adalah sebagai berikut:.

$$
\mathrm{X}_{\mathrm{SA}}+\mathrm{X}_{\mathrm{SB}}+\mathrm{X}_{\mathrm{SC}}+\mathrm{X}_{\mathrm{SD}}=\mathbf{9 3 5 . 7 1 5} \text { ton }
$$

Batasan permintaan (demand) pada masing-masing lokasi distribusi adalah mengambil angka realisasi penjualan semen rata-rata dari tahun 2009 sampai dengan 2012 sebagai berikut.

$\mathrm{X}_{\mathrm{A} 1}+\mathrm{X}_{\mathrm{B} 1}+\mathrm{X}_{\mathrm{C} 1}+\mathrm{X}_{\mathrm{D} 1}=15,038$

$\mathrm{X}_{\mathrm{A} 2}+\mathrm{X}_{\mathrm{B} 2}+\mathrm{X}_{\mathrm{C} 2}+\mathrm{X}_{\mathrm{D} 2}=34,495$

$\mathrm{X}_{\mathrm{A} 3}+\mathrm{X}_{\mathrm{B} 3}+\mathrm{X}_{\mathrm{C} 3}+\mathrm{X}_{\mathrm{D} 3}=13,128$

$\mathrm{X}_{\mathrm{A} 4}+\mathrm{X}_{\mathrm{B} 4}+\mathrm{X}_{\mathrm{C} 4}+\mathrm{X}_{\mathrm{D} 4}=15,529$

$\mathrm{X}_{\mathrm{A} 5}+\mathrm{X}_{\mathrm{B} 5}+\mathrm{X}_{\mathrm{C} 5}+\mathrm{X}_{\mathrm{D} 5}=5,997$

$\mathrm{X}_{\mathrm{A} 6}+\mathrm{X}_{\mathrm{B} 6}+\mathrm{X}_{\mathrm{C} 6}+\mathrm{X}_{\mathrm{D} 6}=34,339$ 


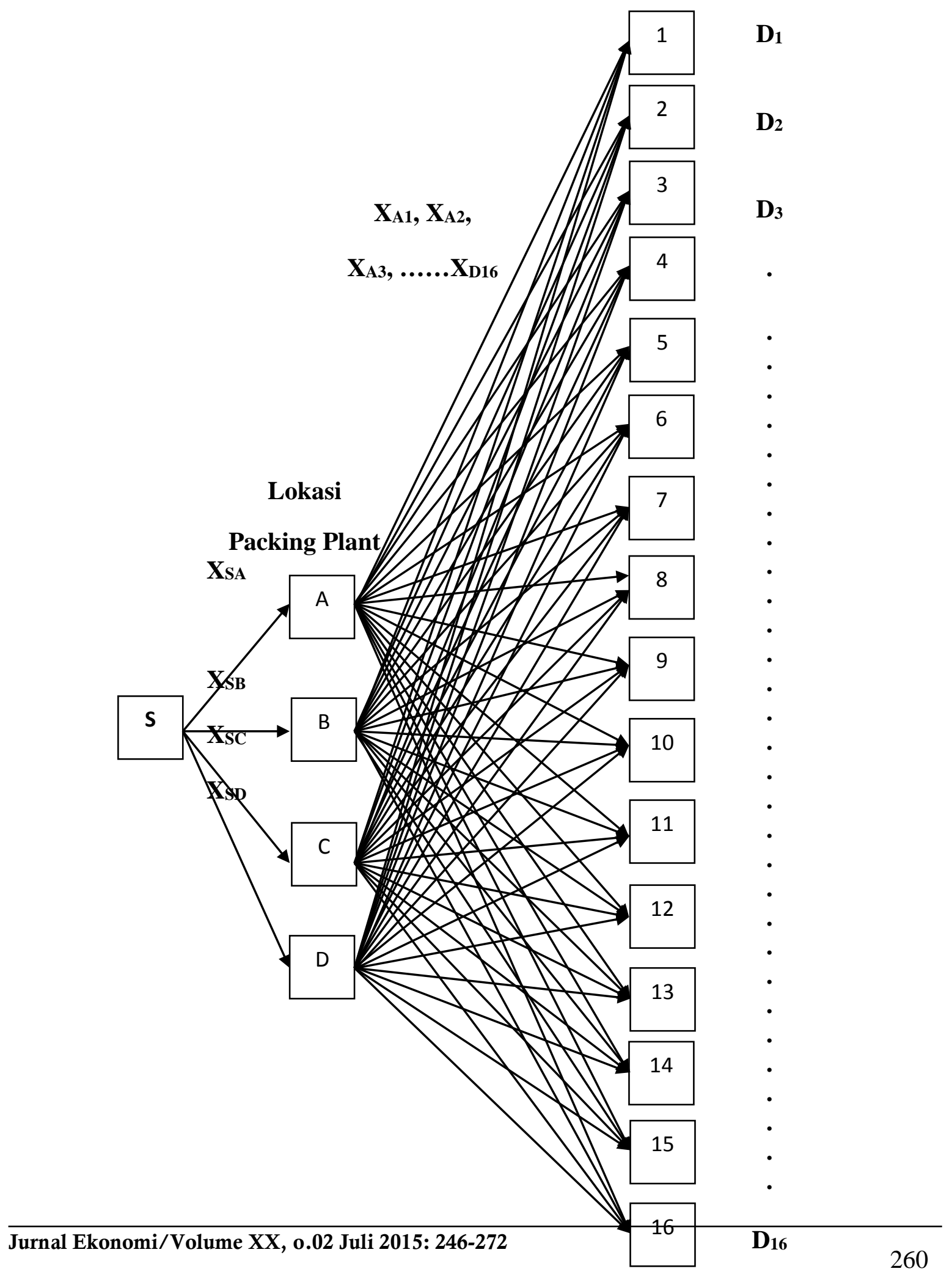


Gambar 6. Model Transshipment distribusi Semen

$\mathrm{X}_{\mathrm{A} 7}+\mathrm{X}_{\mathrm{B} 7}+\mathrm{X}_{\mathrm{C} 7}+\mathrm{X}_{\mathrm{D} 7}=850$

$\mathrm{X}_{\mathrm{A} 8}+\mathrm{X}_{\mathrm{B} 8}+\mathrm{X}_{\mathrm{C} 8}+\mathrm{X}_{\mathrm{D} 8}=113,640$

$\mathrm{X}_{\mathrm{A} 9}+\mathrm{X}_{\mathrm{B} 9}+\mathrm{X}_{\mathrm{C} 9}+\mathrm{X}_{\mathrm{D} 9}=3,554$

$\mathrm{X}_{\mathrm{A} 10}+\mathrm{X}_{\mathrm{B} 10}+\mathrm{X}_{\mathrm{C} 10}+\mathrm{X}_{\mathrm{D} 10}=155,117$

$\mathrm{X}_{\mathrm{A} 11}+\mathrm{X}_{\mathrm{B} 11}+\mathrm{X}_{\mathrm{C} 11}+\mathrm{X}_{\mathrm{D} 11}=87,105$

$\mathrm{X}_{\mathrm{A} 12}+\mathrm{X}_{\mathrm{B} 12}+\mathrm{X}_{\mathrm{C} 12}+\mathrm{X}_{\mathrm{D} 12}=775$

$\mathrm{X}_{\mathrm{A} 13}+\mathrm{X}_{\mathrm{B} 13}+\mathrm{X}_{\mathrm{C} 13}+\mathrm{X}_{\mathrm{D} 13}=236,685$

$\mathrm{X}_{\mathrm{A} 14}+\mathrm{X}_{\mathrm{B} 14}+\mathrm{X}_{\mathrm{C} 14}+\mathrm{X}_{\mathrm{D} 14}=114,658$

$\mathrm{X}_{\mathrm{A} 15}+\mathrm{X}_{\mathrm{B} 15}+\mathrm{X}_{\mathrm{C} 15}+\mathrm{X}_{\mathrm{D} 15}=111,201$

$\mathrm{X}_{\mathrm{A} 16}+\mathrm{X}_{\mathrm{B} 16}+\mathrm{X}_{\mathrm{C} 16}+\mathrm{X}_{\mathrm{D} 16}=59,303$

Selanjutnya batasan yang dibangun adalah batasan pada titik transit yaitu pabrik pengantongan di 4 (empat) wilayah yaitu tuban, Banjarmasin, samarinda dan Pontianak.

Dalam menentukan batasan pada titik transit mengikuti hukum bahwa jumlah yang dikirimkan dari sumber (pabrik semen) ke titik transit dan dari titik transit ke daerah tujuan adalah sama dengan jumlah permintaan pada titik tujuan. Berikut batasan transshipment untuk Packing Plant Tuban:

$$
\mathrm{X}_{\mathrm{SA}}=\mathrm{X}_{\mathrm{A} 1}+\mathrm{X}_{\mathrm{A} 2}+\mathrm{X}_{\mathrm{A} 3}+\mathrm{X}_{\mathrm{A} 4}+\mathrm{X}_{\mathrm{A} 5}+\mathrm{X}_{\mathrm{A} 6}+\mathrm{X}_{\mathrm{A} 7}+\mathrm{X}_{\mathrm{A} 8}+\mathrm{X}_{\mathrm{A} 9}+\mathrm{X}_{\mathrm{A} 10}+\mathrm{X}_{\mathrm{A} 11}+\mathrm{X}_{\mathrm{A} 12}+\mathrm{X}_{\mathrm{A} 13}+\mathrm{X}_{\mathrm{A} 14}+\mathrm{X}_{\mathrm{A} 15}+\mathrm{X}_{\mathrm{A} 16}
$$
atau

$\mathrm{X}_{\mathrm{SA}}-\mathrm{X}_{\mathrm{A} 1}-\mathrm{X}_{\mathrm{A} 2}-\mathrm{X}_{\mathrm{A} 3}-\mathrm{X}_{\mathrm{A} 4}-\mathrm{X}_{\mathrm{A} 5}-\mathrm{X}_{\mathrm{A} 6}-\mathrm{X}_{\mathrm{A} 7}-\mathrm{X}_{\mathrm{A} 8}-\mathrm{X}_{\mathrm{A} 9}-\mathrm{X}_{\mathrm{A} 10}-\mathrm{X}_{\mathrm{A} 11}-\mathrm{X}_{\mathrm{A} 12}-\mathrm{X}_{\mathrm{A} 13}-\mathrm{X}_{\mathrm{A} 14}-\mathrm{X}_{\mathrm{A} 15}-\mathrm{X}_{\mathrm{A} 16}=0$

Batasan transshipment untuk Banjarmasin, Samarinda dan Pontianak adalah sebagai berikut:

$\mathrm{X}_{\mathrm{SB}}-\mathrm{X}_{\mathrm{B} 1}-\mathrm{X}_{\mathrm{B} 2}-\mathrm{X}_{\mathrm{B} 3}-\mathrm{X}_{\mathrm{B} 4}-\mathrm{X}_{\mathrm{B} 5}-\mathrm{X}_{\mathrm{B} 6}-\mathrm{X}_{\mathrm{B} 7}-\mathrm{X}_{\mathrm{B} 8}-\mathrm{X}_{\mathrm{B} 9}-\mathrm{X}_{\mathrm{B} 10}-\mathrm{X}_{\mathrm{B} 11}-\mathrm{X}_{\mathrm{B} 12}-\mathrm{X}_{\mathrm{B} 13}-\mathrm{X}_{\mathrm{B} 14}-\mathrm{X}_{\mathrm{B} 15}-\mathrm{X}_{\mathrm{B} 16}=0$

$\mathrm{X}_{\mathrm{SC}}-\mathrm{X}_{\mathrm{C} 1}-\mathrm{X}_{\mathrm{C} 2}-\mathrm{X}_{\mathrm{C} 3}-\mathrm{X}_{\mathrm{C} 4}-\mathrm{X}_{\mathrm{C} 5}-\mathrm{X}_{\mathrm{C} 6}-\mathrm{X}_{\mathrm{C} 7}-\mathrm{X}_{\mathrm{C} 8}-\mathrm{X}_{\mathrm{C} 9}-\mathrm{X}_{\mathrm{C} 10}-\mathrm{X}_{\mathrm{C} 11}-\mathrm{X}_{\mathrm{C} 12}-\mathrm{X}_{\mathrm{C} 13}-\mathrm{X}_{\mathrm{C} 14}-\mathrm{X}_{\mathrm{C} 15}-\mathrm{X}_{\mathrm{C} 16}=0$

$\mathrm{X}_{\mathrm{SD}}-\mathrm{X}_{\mathrm{D} 1}-\mathrm{X}_{\mathrm{D} 2}-\mathrm{X}_{\mathrm{D} 3}-\mathrm{X}_{\mathrm{D} 4}-\mathrm{X}_{\mathrm{D} 5}-\mathrm{X}_{\mathrm{D} 6}-\mathrm{X}_{\mathrm{D} 7}-\mathrm{X}_{\mathrm{D} 8}-\mathrm{X}_{\mathrm{D} 9}-\mathrm{X}_{\mathrm{D} 10}-\mathrm{X}_{\mathrm{D} 11}-\mathrm{X}_{\mathrm{D} 12}-\mathrm{X}_{\mathrm{D} 13}-\mathrm{X}_{\mathrm{D} 14}-\mathrm{X}_{\mathrm{D} 15}-\mathrm{X}_{\mathrm{D} 16}=$ 0

Dari perumusan dan batasan-batasan diatas maka model matematis lengkap dari penelitian ini adalah:

Meminimumkan

$\mathrm{Z}=\mathrm{X}_{\mathrm{SA}}+\mathrm{X}_{\mathrm{SB}}+\mathrm{X}_{\mathrm{SC}}+\mathrm{X}_{\mathrm{SD}}+\mathrm{X}_{\mathrm{A} 1}+\mathrm{X}_{\mathrm{B} 1}+\mathrm{X}_{\mathrm{C} 1}+\mathrm{X}_{\mathrm{D} 1}+\mathrm{X}_{\mathrm{A} 2}+\mathrm{X}_{\mathrm{B} 2}+\mathrm{X}_{\mathrm{C} 2}+\mathrm{X}_{\mathrm{D} 2}+\mathrm{X}_{\mathrm{A} 3}+\mathrm{X}_{\mathrm{B} 3}+\mathrm{X}_{\mathrm{C} 3}+\mathrm{X}_{\mathrm{D} 3}+\mathrm{X}_{\mathrm{A} 4}$

$+\mathrm{X}_{\mathrm{B} 4}+\mathrm{X}_{\mathrm{C} 4}+\mathrm{X}_{\mathrm{D} 4}+\mathrm{X}_{\mathrm{A} 5}+\mathrm{X}_{\mathrm{B} 5}+\mathrm{X}_{\mathrm{C} 5}+\mathrm{X}_{\mathrm{D} 5}+\mathrm{X}_{\mathrm{A} 6}+\mathrm{X}_{\mathrm{B} 6}+\mathrm{X}_{\mathrm{C} 6}+\mathrm{X}_{\mathrm{D} 6}+\mathrm{X}_{\mathrm{A} 7}+\mathrm{X}_{\mathrm{B} 7}+\mathrm{X}_{\mathrm{C} 7}+\mathrm{X}_{\mathrm{D} 7}+\mathrm{X}_{\mathrm{A} 8}+\mathrm{X}_{\mathrm{B} 8}+$

$\mathrm{X}_{\mathrm{C} 8}+\mathrm{X}_{\mathrm{D} 8}+\mathrm{X}_{\mathrm{A} 9}+\mathrm{X}_{\mathrm{B} 9}+\mathrm{X}_{\mathrm{C} 9}+\mathrm{X}_{\mathrm{D} 9}+\mathrm{X}_{\mathrm{A} 10}+\mathrm{X}_{\mathrm{B} 10}+\mathrm{X}_{\mathrm{C} 10}+\mathrm{X}_{\mathrm{D} 10}+\mathrm{X}_{\mathrm{A} 11}+\mathrm{X}_{\mathrm{B} 11}+\mathrm{X}_{\mathrm{C} 11}+\mathrm{X}_{\mathrm{D} 11}+\mathrm{X}_{\mathrm{A} 12}+\mathrm{X}_{\mathrm{B} 12}$

$+\mathrm{X}_{\mathrm{C} 12}+\mathrm{X}_{\mathrm{D} 12}+\mathrm{X}_{\mathrm{A} 13}+\mathrm{X}_{\mathrm{B} 13}+\mathrm{X}_{\mathrm{C} 13}+\mathrm{X}_{\mathrm{D} 13}+\mathrm{X}_{\mathrm{A} 14}+\mathrm{X}_{\mathrm{B} 14}+\mathrm{X}_{\mathrm{C} 14}+\mathrm{X}_{\mathrm{D} 14}+\mathrm{X}_{\mathrm{A} 15}+\mathrm{X}_{\mathrm{B} 15}+\mathrm{X}_{\mathrm{C} 15}+\mathrm{X}_{\mathrm{D} 15}+\mathrm{X}_{\mathrm{A} 16}$

$+\mathrm{X}_{\mathrm{B} 16}+\mathrm{X}_{\mathrm{C} 16}+\mathrm{X}_{\mathrm{D} 16}$

Dimana

$\mathrm{X}_{\mathrm{SA}}-\mathrm{X}_{\mathrm{A} 1}-\mathrm{X}_{\mathrm{A} 2}-\mathrm{X}_{\mathrm{A} 3}-\mathrm{X}_{\mathrm{A} 4}-\mathrm{X}_{\mathrm{A} 5}-\mathrm{X}_{\mathrm{A} 6}-\mathrm{X}_{\mathrm{A} 7}-\mathrm{X}_{\mathrm{A} 8}-\mathrm{X}_{\mathrm{A} 9}-\mathrm{X}_{\mathrm{A} 10}-\mathrm{X}_{\mathrm{A} 11}-\mathrm{X}_{\mathrm{A} 12}-\mathrm{X}_{\mathrm{A} 13}-\mathrm{X}_{\mathrm{A} 14}-\mathrm{X}_{\mathrm{A} 15}-\mathrm{X}_{\mathrm{A} 16}=0$

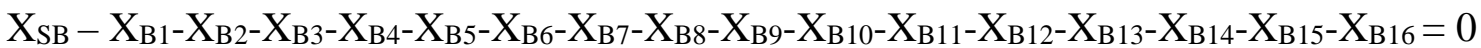

$\mathrm{X}_{\mathrm{SC}}-\mathrm{X}_{\mathrm{C} 1}-\mathrm{X}_{\mathrm{C} 2}-\mathrm{X}_{\mathrm{C} 3}-\mathrm{X}_{\mathrm{C} 4}-\mathrm{X}_{\mathrm{C} 5}-\mathrm{X}_{\mathrm{C} 6}-\mathrm{X}_{\mathrm{C} 7}-\mathrm{X}_{\mathrm{C} 8}-\mathrm{X}_{\mathrm{C} 9}-\mathrm{X}_{\mathrm{C} 10}-\mathrm{X}_{\mathrm{C} 11}-\mathrm{X}_{\mathrm{C} 12}-\mathrm{X}_{\mathrm{C} 13}-\mathrm{X}_{\mathrm{C} 14}-\mathrm{X}_{\mathrm{C} 15}-\mathrm{X}_{\mathrm{C} 16}=0$

$\mathrm{X}_{\mathrm{SD}}-\mathrm{X}_{\mathrm{D} 1}-\mathrm{X}_{\mathrm{D} 2}-\mathrm{X}_{\mathrm{D} 3}-\mathrm{X}_{\mathrm{D} 4}-\mathrm{X}_{\mathrm{D} 5}-\mathrm{X}_{\mathrm{D} 6}-\mathrm{X}_{\mathrm{D} 7}-\mathrm{X}_{\mathrm{D} 8}-\mathrm{X}_{\mathrm{D} 9}-\mathrm{X}_{\mathrm{D} 10}-\mathrm{X}_{\mathrm{D} 11}-\mathrm{X}_{\mathrm{D} 12}-\mathrm{X}_{\mathrm{D} 13}-\mathrm{X}_{\mathrm{D} 14}-\mathrm{X}_{\mathrm{D} 15}-\mathrm{X}_{\mathrm{D} 16}=$ 0 


\section{HASIL DAN PEMBAHASAN}

Kondisi Awal. Kondisi awal adalah distribusi semen gresik dikirim dalam bentuk zak dari pelabuhan Tuban melalui kapal barang (bag vessel) menuju pelabuhan umum di area distribusi. Kemudian dimuat dalam truk barang dengan kapasitas kecil antara 200-300 bag untuk dikirimkan ke seluruh kabupaten-kabupaten di Kalimantan. Semen gresik memiliki dua belas distributor yang men-cover seluruh area dengan total 28 lokasi gudang distributor yang tersebar di 16 kabupaten di Kalimantan. Dengan sistem transportasi seperti demikian, Semen Gresik mengalami Kendala yang dihadapi yaitu: (1) Kapasitas kirim yang rendah karena dikirim dalam bentuk bag dengan armada bag vessel; (2) Kerusakan kemasan di jalan akibat loading dan unloading kapal sehingga memerlukan kantong yang kuat dengan harga yang lebih tinggi; (3) Demoritas kapal akibat bongkar muat ke truk kecil memakan waktu yang cukup lama di pelabuhan. (Departemen Transportasi PT Semen gresik, 2012).

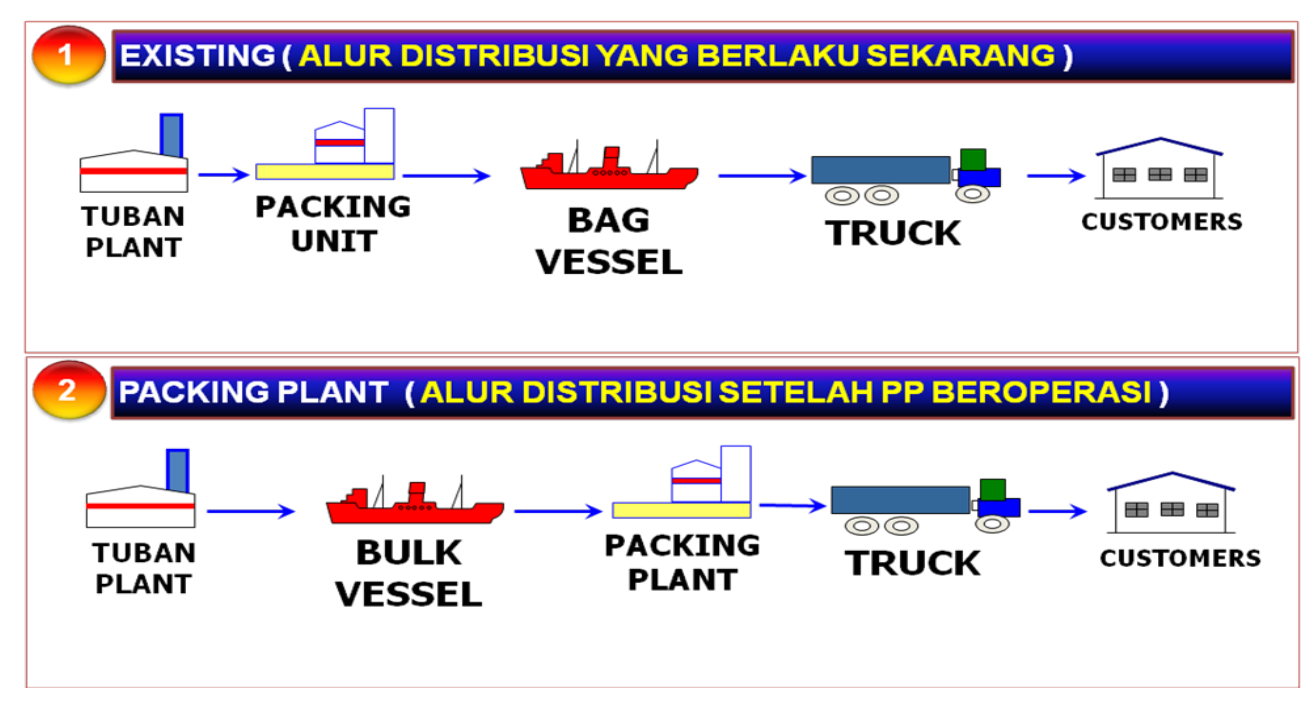

Gambar 7. Alur transportasi semen sebelum dan setelah pemindahan packing plant.

Kondisi Yang Diharapkan. Dalam implementasi program model Transshipment yang bertujuan melakukan efektifitas pengiriman dan efisiensi biaya transportasi semen ke pulau Kalimantan dari pabrik semen di Tuban, Jawa timur, ada hal-hal yang dijadikan pertimbangan yaitu sebagai berikut: (1) Alternatif penyelesaian kendala transportasi semen yaitu dengan membangun pabrik pengemasan di area distribusi di lokasi yang paling tepat dan efisien; (2) Meningkatkan kecepatan pengiriman semen sehingga ketersediaan barang terjamin; (3) Semen Gresik dapat memenuhi permintaan pelanggan, dapat meningkatkan pasar di daerah tersebut dan dapat bersaing dengan kompetitor.

Solusi Model Transshipment. Dalam melakukan proses optimasi penggunaan packing plant sebagai titik transit dalam transportasi semen dari pabrik semen di Tuban ke gudang distribusi di Kalimantan menggunakan software QM for Windows. 
Tabel 7. Hasil Running model Transshipment dengan Software QM for Windows

\begin{tabular}{ccrrr}
\hline \multicolumn{4}{l}{ SHIPPING LIST } & \multicolumn{3}{c}{ Shipment cost } \\
\hline \multicolumn{1}{l}{ From } & To & Shipment & Cost per unit & $13,697,860,000$ \\
L S & A & 124,526 & 110,000 & $63,664,800,000$ \\
S & B & 424,432 & 150,000 & \\
S & C & 72,188 & 247,000 & $17,830,440,000$ \\
S & D & 59,291 & 256,000 & $15,178,500,000$ \\
A & D1 & 5,224 & 400,598 & $2,092,724,000$ \\
A & D3 & 12,988 & 416,948 & $5,415,321,000$ \\
A & D4 & 15,263 & 380,635 & $5,809,632,000$ \\
A & D5 & 6,083 & 320,635 & $1,950,423,000$ \\
A & D7 & 650 & 392,961 & $255,424,700$ \\
A & D8 & 81,711 & 340,785 & $27,845,880,000$ \\
A & D9 & 2,607 & 373,968 & $974,934,600$ \\
A & A & 555,911 & - & - \\
B & D10 & 112,667 & 274,000 & $30,870,760,000$ \\
B & D11 & 64,936 & 176,000 & $11,428,740,000$ \\
B & D12 & 584 & 99,000 & $57,816,000$ \\
B & D13 & 165,824 & 92,000 & $15,255,810,000$ \\
B & D14 & 80,421 & 99,000 & $7,961,679,000$ \\
B & B & 256,005 & - & - \\
C & D2 & 35,645 & 92,000 & $3,279,340,000$ \\
C & D6 & 36,543 & 174,000 & $6,358,482,000$ \\
C & C & 608,249 & - & - \\
D & D15 & 31,139 & 92,000 & $2,864,788,000$ \\
D & D16 & 28,152 & 99,000 & - \\
D & D & 621,146 & - & $-048,000$ \\
\hline
\end{tabular}

Tabel 8. Hasil Running model Transportasi dengan Data Demand 2009

\begin{tabular}{|c|c|c|c|c|}
\hline \multicolumn{5}{|c|}{ SHIPPING LIST } \\
\hline From & To & Shipment & Cost per unit & Shipment cost \\
\hline $\mathrm{S}$ & A & 157,035 & 110,000 & $17,273,850,000$ \\
\hline $\mathrm{S}$ & B & 524,523 & 150,000 & $78,678,450,000$ \\
\hline $\mathrm{S}$ & $\mathrm{C}$ & 91,664 & 247,000 & $22,641,010,000$ \\
\hline $\mathrm{S}$ & $\mathrm{D}$ & 78,869 & 256,000 & $20,190,460,000$ \\
\hline A & D1 & 6,633 & 400,598 & $2,657,167,000$ \\
\hline A & D3 & 16,493 & 416,948 & $6,876,723,000$ \\
\hline A & D4 & 19,380 & 380,635 & $7,376,706,000$ \\
\hline A & D5 & 7,725 & 320,635 & $2,476,905,000$ \\
\hline A & D7 & 817 & 392,961 & $321,049,200$ \\
\hline $\mathrm{A}$ & D8 & 102,710 & 340,785 & $35,002,030,000$ \\
\hline
\end{tabular}




\begin{tabular}{|c|c|c|c|c|}
\hline A & D9 & 3,277 & 373,968 & $1,225,493,000$ \\
\hline A & A & 695,056 & - & - \\
\hline $\mathrm{B}$ & D10 & 141,621 & 274,000 & $38,804,150,000$ \\
\hline \multicolumn{2}{|c|}{$\begin{array}{cc}\text { B } & \text { D11 } \\
\text { Lanjutan Tabel } 8\end{array}$} & 81,624 & 176,000 & $\begin{array}{r}14,365,820,000 \\
70,587,000\end{array}$ \\
\hline B & D12 & 713 & 99,000 & \\
\hline B & D13 & 202,403 & 92,000 & $18,621,080,000$ \\
\hline B & D14 & 98,162 & 99,000 & $9,718,038,000$ \\
\hline $\mathrm{B}$ & B & 327,568 & - & - \\
\hline $\mathrm{C}$ & D2 & 45,261 & 92,000 & $4,164,012,000$ \\
\hline $\mathrm{C}$ & D6 & 46,403 & 174,000 & $8,074,122,000$ \\
\hline $\mathrm{C}$ & $\mathrm{C}$ & 760,427 & - & - \\
\hline $\mathrm{D}$ & D15 & 41,421 & 92,000 & $3,810,732,000$ \\
\hline $\mathrm{D}$ & D16 & 37,448 & 99,000 & $3,707,352,000$ \\
\hline $\mathrm{D}$ & $\mathrm{D}$ & 773,222 & - & - \\
\hline
\end{tabular}

Tabel 9. Hasil Running model Transportasi dengan Data Demand 2010

\begin{tabular}{|c|c|c|c|c|}
\hline \multicolumn{5}{|c|}{ SHIPPING LIST } \\
\hline From & To & Shipment & Cost per unit & Shipment cost \\
\hline $\mathrm{S}$ & A & 157,250 & 110,000 & $17,297,500,000$ \\
\hline S & $\mathrm{B}$ & 522,849 & 150,000 & $78,427,350,000$ \\
\hline $\mathrm{S}$ & $\mathrm{C}$ & 83,102 & 247,000 & $20,526,190,000$ \\
\hline $\mathrm{S}$ & $\mathrm{D}$ & 101,776 & 256,000 & $26,054,660,000$ \\
\hline A & $\mathrm{D} 1$ & 6,014 & 400,598 & $2,409,196,000$ \\
\hline A & D3 & 14,952 & 416,948 & $6,234,207,000$ \\
\hline $\mathrm{A}$ & D4 & 17,570 & 380,635 & $6,687,757,000$ \\
\hline A & D5 & 7,003 & 320,635 & $2,245,407,000$ \\
\hline A & D7 & 855 & 392,961 & $335,981,700$ \\
\hline A & D8 & 107,428 & 340,785 & $36,609,850,000$ \\
\hline A & D9 & 3,428 & 373,968 & $1,281,962,000$ \\
\hline A & $\mathrm{A}$ & 707,728 & - & - \\
\hline $\mathrm{B}$ & D10 & 148,127 & 274,000 & $40,586,800,000$ \\
\hline $\mathrm{B}$ & D11 & 85,373 & 176,000 & $15,025,650,000$ \\
\hline $\mathrm{B}$ & D12 & 684 & 99,000 & $67,716,000$ \\
\hline $\mathrm{B}$ & D13 & 194,390 & 92,000 & $17,883,880,000$ \\
\hline B & D14 & 94,275 & 99,000 & $9,333,225,000$ \\
\hline $\mathrm{B}$ & B & 342,129 & - & - \\
\hline $\mathrm{C}$ & $\mathrm{D} 2$ & 41,034 & 92,000 & $3,775,128,000$ \\
\hline $\mathrm{C}$ & D6 & 42,068 & 174,000 & $7,319,832,000$ \\
\hline $\mathrm{C}$ & $\mathrm{C}$ & 781,876 & - & - \\
\hline $\mathrm{D}$ & D15 & 53,451 & 92,000 & $4,917,492,000$ \\
\hline $\mathrm{D}$ & D16 & 48,325 & 99,000 & $4,784,175,000$ \\
\hline
\end{tabular}




D $\quad$ D $\quad 763,202$

Tabel 10. Hasil Running model Transportasi dengan Data Demand 2011

\begin{tabular}{|l|l|r|r|c|}
\hline \multicolumn{5}{|l}{ SHIPPING LIST } \\
\hline From & To & \multicolumn{1}{l}{ Shipment } & Cost per unit & Shipment cost \\
\hline S & A & 148,169 & 110,000 & $16,298,590,000$ \\
\hline S & B & 559,848 & 150,000 & $83,977,200,000$ \\
\hline S & C & 67,711 & 247,000 & $16,724,620,000$ \\
\hline S & D & 159,987 & 256,000 & $40,956,670,000$ \\
\hline A & D1 & 4,900 & 400,598 & $1,962,930,000$ \\
\hline A & D3 & 12,179 & 416,948 & $5,078,010,000$ \\
\hline A & D4 & 14,316 & 380,635 & $5,449,170,000$ \\
\hline A & D5 & 5,706 & 320,635 & $1,829,543,000$ \\
\hline A & D7 & 850 & 392,961 & $334,016,900$ \\
\hline A & D8 & 106,810 & 340,785 & $36,399,250,000$ \\
\hline A & D9 & 3,408 & 373,968 & $1,274,483,000$ \\
\hline A & A & 787,546 & & - \\
\hline B & D10 & 147,274 & 274,000 & $40,353,080,000$ \\
\hline B & D11 & 84,882 & 176,000 & $14,939,230,000$ \\
\hline B & D12 & 775 & 99,000 & $76,725,000$ \\
\hline B & D13 & 220,149 & 92,000 & $20,253,710,000$ \\
\hline B & D14 & 106,768 & 99,000 & $10,570,030,000$ \\
\hline B & B & 375,867 & & - \\
\hline C & D2 & 33,434 & 92,000 & $3,075,928,000$ \\
\hline C & D6 & 34,277 & 174,000 & $5,964,198,000$ \\
\hline C & C & 868,004 & & - \\
\hline D & D15 & 104,897 & 92,000 & $9,650,524,000$ \\
\hline D & D16 & 55,090 & 99,000 & $5,453,910,000$ \\
\hline D & D & 775,728 & & - \\
\hline
\end{tabular}

Dari Tabel 7 sampai dengan Tabel 10 diketahui urutan alternative alur distribusi dengan membangun packing plant di area distribusi sebagai titik transit transportasi yang paling efisien untuk distribusi semen ke Kalimantan. Urutannya yaitu Banjarmasin, Pontianak baru kemudian Samarinda.

Pada Tabel 11 jumlah semen yang di distribusikan melalui Banjarmasin selalu lebih tinggi disbanding lokasi lain, karena biaya distribusi yang lebih murah dan jarak yang lebih dekat. Dari tabel diatas, jika PT Semen Gresik akan membangun packing plant di Banjarmasin maka memerlukan dua unit packing plant untuk dapat memenuhi demand yang ada yaitu dengan total kapasitas 600.000 ton per tahun. pada Pontianak dan 
Samarinda jika dibangun hanya memerlukan satu unit, namun penggunaannya kurang efektif karena total demand per tahun masih jauh dibawah kapasitas packing plant yaitu 300.000 ton / tahun.

Tabel 11. Perbandingan Total Demand Per Lokasi Packing Plant per Tahun (Ton/tahun)

\begin{tabular}{lrlll}
\hline & PP TUBAN & PP BANJARMASIN & PP SAMARINDA & PP PONTIANAK \\
\hline 2009 & 124,526 & 424,432 & 72,188 & 59,291 \\
2010 & 157,035 & 524,523 & 91,664 & 78,869 \\
2011 & 157,250 & 522,849 & 83,102 & 101,776 \\
2012 & 148,169 & 559,848 & 67,711 & 159,987 \\
\hline
\end{tabular}

Tabel 12. Perbandingan Biaya Distribusi Sebelum dan Setelah Ada Packing Plant (Rp)

\begin{tabular}{lrllll}
\hline & 2009 & 2010 & 2011 & 2012 \\
\hline Dikirim & Dari & & & & \\
Tuban & & $300,600,100,600$ & $376,880,278,800$ & $383,328,960,400$ & $413,651,207,300$ \\
$\begin{array}{l}\text { Dengan } \\
\text { Sebagai }\end{array}$ & Pp & & & & \\
Transit & & $235,580,402,300$ & $296,055,736,200$ & $301,803,958,700$ & $320,621,817,900$ \\
\hline
\end{tabular}

Dari Tabel di atas, dengan adanya packing plant di area distribusi menghemat biaya distribusi dan transportasi rata-rata $22 \%$ per tahun.

Proyeksi demand. Dasar penetapan tahun proyeksi adalah hipotesis dari studi kelayakan yang dilakukan Semen Gresik yaitu masa pengembalian modal investasi packing plant rata-rata adalah 6 sampai 7 tahun. Sehingga jika pembangunan pabrik kemasan di Kalimantan dimulai tahun 2013 maka BEP akan terjadi pada tahun 2020.

Untuk mendapatkan nilai demand di tahun 2020, didapat dari rata-rata presentase pertumbuhan demand di Kalimantan per tahun mulai tahun 2009 sampai 2012 yaitu sebesar $11.7 \%$.

Tabel 13. Proyeksi Pertumbuhan Demand di Kalimantan.

\begin{tabular}{|c|c|c|c|c|c|c|c|c|c|c|}
\hline AREA & 2011 & 2012 & 2013 & 2014 & 2015 & 2016 & 2017 & 2018 & 2019 & 2020 \\
\hline Ketapang & 48,325 & 55,090 & 61,536 & 68,735 & 76,777 & 85,760 & 95,794 & 107,002 & 119,521 & - \\
\hline Pontianak & 53,451 & 104,893 & 117,165 & 130,874 & 146,186 & 163,290 & 182,395 & 203,735 & 227,572 & 269,484 \\
\hline
\end{tabular}




\begin{tabular}{|c|c|c|c|c|c|c|c|c|c|c|}
\hline Banjar & 94,275 & 106,768 & 119,260 & 133,213 & 148,799 & 166,209 & 185,655 & 207,377 & 231,640 & 277,862 \\
\hline Banjarmasin & 194,390 & 220,149 & 245,906 & 274,677 & 306,815 & 342,712 & 382,809 & 427,598 & 477,627 & 573,582 \\
\hline $\begin{array}{l}\text { Kotawaringin } \\
\text { Barat }\end{array}$ & 684 & 775 & 866 & 967 & 1,080 & 1,206 & 1,348 & 1,505 & 1,681 & 1,878 \\
\hline $\begin{array}{l}\text { Kotawaringin } \\
\text { Timur }\end{array}$ & 85,373 & 84,882 & 94,813 & 105,906 & 118,297 & 132,138 & 147,598 & 164,867 & 184,157 & 415,463 \\
\hline Palangkaraya & 148,127 & 147,274 & 164,505 & 183,752 & 205,251 & 229,266 & 256,090 & 286,052 & 319,520 & 375,910 \\
\hline Seruyan & 3,428 & 3,408 & 3,807 & 4,252 & 4,750 & 5,305 & 5,926 & 6,619 & 7,394 & 8,612 \\
\hline Teluk Kumai & 107,428 & 106,810 & 119,307 & 133,266 & 148,858 & 166,274 & 185,728 & 207,458 & 231,731 & 275,395 \\
\hline Bukit Pinang & 855 & 850 & 949 & 1,061 & 1,185 & 1,323 & 1,478 & 1,651 & 1,844 & 2,060 \\
\hline Balikpapan & 42,068 & 34,277 & 38,287 & 42,767 & 47,771 & 53,360 & 59,603 & 66,577 & 74,366 & 83,218 \\
\hline Berau & 7,003 & 5,706 & 6,374 & 7,119 & 7,952 & 8,883 & 9,922 & 11,083 & 12,380 & 14,534 \\
\hline Bulungan & 17,570 & 14,316 & 15,991 & 17,862 & 19,952 & 22,286 & 24,894 & 27,806 & 31,059 & 37,633 \\
\hline Nunukan & 14,952 & 12,183 & 13,608 & 15,201 & 16,979 & 18,966 & 21,185 & 23,663 & 26,432 & 31,815 \\
\hline Samarinda & 41,034 & 33,434 & 37,346 & 41,715 & 46,596 & 52,048 & 58,137 & 64,939 & 72,537 & 83,596 \\
\hline Tarakan & 6,014 & 4,900 & 5,473 & 6,114 & 6,829 & 7,628 & 8,520 & 9,517 & 10,631 & 36,442 \\
\hline $\begin{array}{c}\text { TOTAL } \\
\text { Kalimantan }\end{array}$ & 864,978 & 935,715 & $\begin{array}{c}1,045,1 \\
94\end{array}$ & $1,167,481$ & 1,304,077 & $1,456,654$ & $1,627,082$ & $1,817,451$ & $2,030,092$ & $2,426,826$ \\
\hline Growth & & $8 \%$ & $11.7 \%$ & $11.7 \%$ & $11.7 \%$ & $11.7 \%$ & $11.7 \%$ & $11.7 \%$ & $11.7 \%$ & $11.7 \%$ \\
\hline
\end{tabular}

Analisa Skenario. Analisa skenario dilakukan untuk mencari prioritas pembangunan plant dan besarnya kapasitas yang diperlukan. Urutan skenario perbandingan efisiensi biaya distribusi ke Kalimantan didasari dari hasil running model pada QM for windows. Running model per skenario menggunakan data proyeksi demand tahun 2027, yaitu 15 tahun sejak dimulainya pembangunan sesuai perkiraan umur ekonomis investasi pabrik pengantongan yang telah diprediksi oleh perusahaan. (Semen Gresik, 2011).

Skenario I, yaitu semua distribusi semen ke Kalimantan adalah dikemas dalam zak (50 kg) di Tuban dan dikirim ke seluruh area distribusi dari pelabuhan Tuban. Menggunakan data demand tahun 2027.

Tabel 14. Hasil running skenario I model T ransportasi pada QM for Windows

\begin{tabular}{ccccc}
\hline From & To & Shipment & Cost per unit & Shipment cost \\
\hline S & D3 & - & $10,000,000$ & - \\
S & A & $2,267,613$ & 110,000 & $249,437,400,000$ \\
A & D1 & 11,875 & 400,598 & $4,757,101,000$ \\
A & D2 & 81,024 & 357,028 & $28,927,840,000$ \\
A & D3 & 29,524 & 416,948 & $12,309,970,000$ \\
A & D4 & 34,693 & 380,635 & $13,205,370,000$ \\
A & D5 & 13,828 & 320,635 & $4,433,741,000$ \\
A & D6 & 83,067 & 334,858 & $27,815,650,000$ \\
A & D7 & 2,060 & 392,961 & $809,499,600$ \\
A & D8 & 258,844 & 340,785 & $88,210,150,000$ \\
\hline
\end{tabular}


Atrisyanti: sudi Penggunaan Packing Plant Pada Distribusi Semen...

\begin{tabular}{ccccc}
\hline \hline & \multicolumn{5}{c}{} \\
\hline A & D9 & 8,259 & 373,968 & $3,088,602,000$ \\
A & D10 & 356,904 & 385,558 & $137,607,200,000$ \\
A & D11 & 205,703 & 298,128 & $61,325,820,000$ \\
A & D12 & 1,878 & 296,754 & $557,304,000$ \\
A & D13 & 533,509 & 295,781 & $157,801,800,000$ \\
A & D14 & 258,742 & 294,278 & $76,142,080,000$ \\
A & D15 & 254,198 & 352,677 & $89,649,790,000$ \\
A & D16 & 133,505 & 347,285 & $46,364,280,000$ \\
A & A & $1,387,535$ & - & - \\
\hline
\end{tabular}

Skenario II, yaitu semen dikirim sebagian dari Tuban dalam bentuk zak (50kg) dan sebagian dikirim ke PP di Banjarmasin dalam curah, dikemas di Banjarmasin dan didistribusikan ke gudang distributor di area yang terjangkau dari Banjarmasin.

Tabel 15. Hasil running skenario II model T ransportasi pada QM for Windows

\begin{tabular}{ccccc}
\hline From & To & Shipment & Cost per unit & Shipment cost \\
\hline S & A & 910,877 & 110,000 & $100,196,500,000$ \\
S & B & $1,356,736$ & 150,000 & $203,510,400,000$ \\
A & D1 & 11,875 & 400,598 & $4,757,101,000$ \\
A & D2 & 81,024 & 357,028 & $28,927,840,000$ \\
A & D3 & 29,524 & 416,948 & $12,309,970,000$ \\
A & D4 & 34,693 & 380,635 & $13,205,370,000$ \\
A & D5 & 13,828 & 320,635 & $4,433,741,000$ \\
A & D6 & 83,067 & 334,858 & $27,815,650,000$ \\
A & D7 & 2,060 & 392,961 & $809,499,600$ \\
A & D8 & 258,844 & 340,785 & $88,210,150,000$ \\
A & D9 & 8,259 & 373,968 & $3,088,602,000$ \\
A & D15 & 254,198 & 352,677 & $89,649,790,000$ \\
A & D16 & 133,505 & 347,285 & $46,364,280,000$ \\
A & A & $1,356,736$ & - & - \\
B & D10 & 356,904 & 274,000 & $97,791,700,000$ \\
B & D11 & 205,703 & 176,000 & $36,203,730,000$ \\
B & D12 & 1,878 & 99,000 & $185,922,000$ \\
B & D13 & 533,509 & 92,000 & $49,082,830,000$ \\
B & D14 & 258,742 & 99,000 & $25,615,460,000$ \\
B & B & 910,877 & - & - \\
\hline
\end{tabular}

Skenario III, yaitu semen dikirim dari Tuban langsung, dan atau dikirim dari Banjarmasin dan Pontianak sebagai titik transit.

Tabel 16. Hasil running skenario III model T ransportasi pada QM for Windows

\begin{tabular}{ccccc}
\hline From & To & Shipment & Cost per unit & Shipment cost \\
\hline S & A & 523,174 & 110,000 & $57,549,140,000$ \\
S & B & $1,356,736$ & 150,000 & $203,510,400,000$ \\
S & C & 387,703 & 247,000 & $95,762,640,000$ \\
A & D1 & 11,875 & 400,598 & $4,757,101,000$ \\
A & D2 & 81,024 & 357,028 & $28,927,840,000$ \\
\hline
\end{tabular}




\begin{tabular}{|c|c|c|c|c|}
\hline $\mathrm{A}$ & D3 & 29,524 & 416,948 & $12,309,970,000$ \\
\hline A & D4 & 34,693 & 380,635 & $13,205,370,000$ \\
\hline A & D5 & 13,828 & 320,635 & 4,433,741,000 \\
\hline \multicolumn{2}{|c|}{ Ląniuan Tabøb 66} & 83,067 & 334,858 & $27,815,650,000$ \\
\hline $\mathrm{A}$ & D7 & 2,060 & 392,961 & $809,499,600$ \\
\hline A & D8 & 258,844 & 340,785 & $88,210,150,000$ \\
\hline A & D9 & 8,259 & 373,968 & $3,088,602,000$ \\
\hline A & A & $1,744,439$ & - & - \\
\hline $\mathrm{B}$ & D10 & 356,904 & 274,000 & $97,791,700,000$ \\
\hline $\mathrm{B}$ & D11 & 205,703 & 176,000 & $36,203,730,000$ \\
\hline $\mathrm{B}$ & D12 & 1,878 & 99,000 & $185,922,000$ \\
\hline B & D13 & 533,509 & 92,000 & $49,082,830,000$ \\
\hline $\mathrm{B}$ & D14 & 258,742 & 99,000 & $25,615,460,000$ \\
\hline $\mathrm{B}$ & B & 910,877 & - & - \\
\hline $\mathrm{D}$ & D15 & 254,198 & 92,000 & $23,386,220,000$ \\
\hline $\mathrm{D}$ & D16 & 133,505 & 99,000 & $13,217,000,000$ \\
\hline $\mathrm{D}$ & $\mathrm{C}$ & $1,879,910$ & - & - \\
\hline
\end{tabular}

Skenario IV, yaitu semen dikirim dari 3 lokasi, dari tuban langsung, dari pp di Banjarmasin, dari pp di Pontianak dan dari pp samarinda.

Tabel 17. Hasil running skenario IV model T ransportasi pada QM for Windows

\begin{tabular}{ccccc}
\hline From & To & Shipment & Cost per unit & Shipment cost \\
\hline S & A & 359,083 & 110,000 & $39,499,130,000$ \\
S & B & $1,356,736$ & 150,000 & $203,510,400,000$ \\
S & C & 164,091 & 247,000 & $40,530,480,000$ \\
S & D & 387,703 & 256,000 & $99,251,970,000$ \\
A & D1 & 11,875 & 400,598 & $4,757,101,000$ \\
A & D3 & 29,524 & 416,948 & $12,309,970,000$ \\
A & D4 & 34,693 & 380,635 & $13,205,370,000$ \\
A & D5 & 13,828 & 320,635 & $4,433,741,000$ \\
A & D7 & 2,060 & 392,961 & $809,499,600$ \\
A & D8 & 258,844 & 340,785 & $88,210,150,000$ \\
A & D9 & 8,259 & 373,968 & $3,088,602,000$ \\
A & A & $1,908,530$ & - & - \\
B & D10 & 356,904 & 274,000 & $97,791,700,000$ \\
B & D11 & 205,703 & 176,000 & $36,203,730,000$ \\
B & D12 & 1,878 & 99,000 & $185,922,000$ \\
B & D13 & 533,509 & 92,000 & $49,082,830,000$ \\
B & D14 & 258,742 & 99,000 & $25,615,460,000$ \\
B & B & 910,877 & - & - \\
C & D2 & 81,024 & 92,000 & $7,454,208,000$ \\
C & D6 & 83,067 & 174,000 & $14,453,660,000$ \\
\hline
\end{tabular}




\begin{tabular}{ccccc}
\hline C & C & $2,103,522$ & - & - \\
D & D15 & 254,198 & 92,000 & $23,386,220,000$ \\
D & D16 & 133,505 & 99,000 & $13,217,000,000$ \\
D & D & $1,879,910$ & - & - \\
\hline
\end{tabular}

Perbandingan total biaya distribusi dari masing-masing scenario:

Tabel 18. Perbandingan Skenario

\begin{tabular}{lc}
\hline Skenario & Total Biaya Distribusi \\
\hline Skenario 1 (PP Tuban) & $1,002,443,597,600$ \\
Skenario 2 (PP Tuban \& PP Banjarmasin) & $832,158,535,600$ \\
Skenario 3 (PP Tuban, PP Banjarmasin \& PP Pontianak) & $785,862,965,600$ \\
Skenario 4 (PP Tuban, PP Banjarmasin, PP Pontianak & $776,997,143,600$ \\
\hline
\end{tabular}

Dari keempat skenario diatas, model alternatif scenario ke-empat menjadi solusi sementara karena memiliki total biaya distribusi terendah yaitu Rp 776,997,143,600,-. Solusi diatas didapat dengan me-running model transshipment yang sesuai kondisi trasnportasi semen saat ini dan jika menggunakan packing plant sebagai titik transit. Komponen biaya yang dianalisis adalah biaya operasional saja. Namun perlu dianalisis kembali bila biaya investasi packing plant dimasukkan dalam total biaya distribusi dan transportasinya.

Analisis dengan memperhitungkan biaya investasi. Dari hasil studi lapangan dan data perusahaan, nilai investasi pembangunan satu unit packing plant lengkap dilengkapi dengan dermaga, dua unit silo kapasitas masing-masing 3500 ton, jembatan timbang, serta perlengkapan bongkar muat adalah senilai Rp 120.200.000.000,- dengan kapasitas 300.000 ton per tahun. Berdasarkan data dari PT Semen Gresik, asumsi umur ekonomis unit packing plant adalah 15 tahun. Untuk menentukan alternatif biaya distribusi paling efisien maka nilai investasi ditambahkan pada biaya transportasi semen bila dibangun packing plant di Kalimantan. Nilai investasi dikalikan faktor perumusan pengembalian modal (capital recovery factor) yang didapatkan dari tabel pemajemukan diskrit. (Pujawan, 2008).

Dengan asumsi interest rate (i) sebesar 6\% dan masa pengembalian modal (n) adalah 7 tahun maka didapatkan:

$$
120,200,000,000 \times 0.1030=12,380,600,000,-
$$

Maka perbandingan total biaya distribusi berdasarkan empat analisa scenario diatas dengan memperhitungkan nilai investasi adalah sebagai berikut:

Tabel 19. Perbandingan skenario dengan mempertimbangkan biaya investasi

\begin{tabular}{|l|c|c|c|c|}
\hline \multicolumn{1}{|c|}{ Skenario } & $\begin{array}{c}\text { Total Biaya } \\
\text { Distribusi (Rp/th) } \\
\text { (a) }\end{array}$ & $\begin{array}{c}\text { Investasi } \\
\text { Packing } \\
\text { plant } \\
\text { (unit) (b) }\end{array}$ & $\begin{array}{c}\text { Nilai Investasi } \\
\text { x Capital } \\
\text { Recovery } \\
\text { Factor ( c ) }\end{array}$ & a + (b x c) \\
\hline Skenario 1 (PP Tuban) & $1,002,443,597,600$ & 0 & $21,527,820,000$ & $1,002,443,597,600$ \\
\hline $\begin{array}{l}\text { Skenario 2 (PP Tuban \& PP } \\
\text { Banjarmasin) }\end{array}$ & $832,158,535,600$ & 2 & $21,527,820,000$ & $875,214,175,600$ \\
\hline
\end{tabular}




\begin{tabular}{|l|c|c|c|c|} 
Skenario 3 (PP Tuban, PP & $785,862,965,600$ & 3 & $21,527,820,000$ & $850,446,425,600$ \\
Banjarmasin \& PP Pontianak) & (P) & 3 & $21,527,820,000$ & $863,108,423,600$ \\
\hline $\begin{array}{l}\text { Skenario 4 (PP Tuban, PP } \\
\text { Banjarmasin, PP Pontianak dan } \\
\text { Samarinda) }\end{array}$ & $776,997,143,600$ & 4 & \\
\hline
\end{tabular}

Dari Tabel 19 diketahui bahwa solusi optimal meminimumkan biaya distribusi adalah pada scenario ke tiga. Yaitu dengan membangun dua unit packing plant di Banjarmasin (kapasitas 600.000 ton/tahun) dan satu unit packing plant di Pontianak (kapasitas 300.000 ton/tahun).

\section{PENUTUP}

Kesimpulan Pertama. Dari hasil pengumpulan data dan studi lapangan, dibangun model Transshipment untuk meminimumkan biaya distribusi Semen Gresik ke Kalimantan dengan alur model sebagai berikut: Pabrik PT Semen Gresik di Tuban sebagai sumber (source) kemudian dikirim melalui empat titik transit $(\mathrm{T})$. Titik transit yang pertama adalah packing plant eksisting di Tuban sebagai titik transit murni (T), titik transit kedua, ketiga dan keempat adalah titik transit merangkap fungsi tujuan yaitu packing plant di Banjarmasin, Samarinda dan Pontianak $\left(\mathrm{T}_{\mathrm{D}}\right)$. Dari titik transit tersebut kemudian dikirim ke gudang distributor di enam belas Kota sebagai area tujuan distribusi (D). Kedua. Hasil analisa model Transshipment diketahui bahwa biaya distribusi Semen Gresik akan lebih efisien bila dibangun packing plant mendekati area distribusinya. Sebelum dibangun packing plant di Kalimantan total biaya distribusi tahun 2012 adalah Rp 413,651,207,300,dan jika dibangun packing plant di Kalimantan adalah Rp 320,621,817,900,-. Pembangun packing plant di Kalimantan juga menjadi alternatif distribusi yang lebih cepat karena memiliki cycletime lebih cepat dan daya tampung kapal lebih besar sehingga ketersediaan stok semen terjamin. Ketiga. Dari ke empat analisa skenario, maka skenario III merupakan alternatif alur distribusi semen dalam bentuk zak paling efektif dimana packing plant dibangun di Banjarmasin dengan kapasitas 600.000 ton per tahun dan di Pontianak dengan kapasitas 300.000 ton per tahun,. Skenario III ini dapat membuat PT Semen Gresik dapat menghemat biaya distribusi Rp 127,229,422,000,- di tahun 2020 dari total biaya distribusi sebesar Rp 1,002,443,597,600 jika tanpa membangun packing plant menjadi Rp 850,446,425,600 dengan adanya packing plant. Sehingga PT Semen Gresik dapat memperluas pasar di Kalimantan.

Saran. Pertama. Untuk penelitian selanjutnya disarankan memperhitungkan lebih detail mengenai kemungkinan koordinasi pengiriman semen dari ketiga perusahaan dalam semen gresik group. Kedua. Memperhitungkan mengenai dampak-dampak lingkungan yang terjadi dengan adanya pembangunan packing plant.

\section{DAFTAR RUJUKAN}

Taylor III, Bernard W., (2004) "Introduction to Management Science", Eight Edition, International Edition, Prentice Hall, Pearson Education, Inc., Upper Saddle River, New Jersey. 
Law, A. M., and Kelton, W. D. (1991) Simulation modeling and Analysis : McGraw-Hill, New York.

Anwar, N., (2000) "Analisis Sistim dan Penelitian Operasional", Modul Kuliah, Jurusan Teknik Sipil FTSP ITS, Surabaya.

Ossenbruggen, P.J., (1984) "System Analysis for Civil Engineers: Technological and Economic Factors in Design", John Willey \& Sons, New York.

Render, B., Stair Jr, R.M. and Hanna, M.E., (2003) "Quantitative Analysis for Management", Eight Edition, International Edition, Prentice Hall, Pearson Education, Inc., Upper Saddle River, New Jersey.

Supranto, J., (1998) "Teknik Pengambilan Keputusan", Rineka Cipta, Jakarta..

Taha, H.A., (2003) "Operations Research: an Introduction", Seventh Edition, International Edition, Prentice Hall, Pearson Education, Inc., Upper Saddle River, New Jersey.

PT Semen Gresik, (2011) “Laporan tahunan 2010 dan 2011”.

Agustini, D.H. \& Rahmadi, E. (2004) Riset Operasional Konsep-konsep Dasar. Jakarta: PT Rineka Cipta.

Ayudina, P.E \& Widayanti, M. (2002) ”Model Transshipment Guna Menghasilkan Biaya Pendistribusian yang Minimum Melalui Kajian Teoritis". Jurnal Teknik Industri Optimum, 3 (1): 75-84.

Dimyati, T.T. \& Dimyati, A. (2004) Operations Research; Model-model pengambilan keputusan. Bandung: Sinar Baru Algensindo.

Dwijanto. (2007) Program Linear Berbantuan Komputer: Lindo, Lingo dan Solver. Semarang: UNNES PRESS.

Ekren, B.Y \& Heragu, S.S. (2008) Simulation Based Optimization Of MultiLocation Transshipment Problem With Capacitated Transportation. Proceedings of the 2008 Winter Simulation Conference. Louisville: University of Louisville.

Siswanto. (2007) Operations Research. Yogyakarta: Erlangga.

http://www.majalahpotretindonesia.com/index.php/ekbis/405-perluas-area-pemasaran semen-gresik-bangun-15-pabrik-pengemasan. Diakses Tanggal: 15 Januari 2013.

http://www.mediaindonesia.com/read/2012/08/09/339552/21/2/Semen-Gresik-Perluas Pasar-ke-Kalimantan-dan-Papua. Diakses Tanggal : 15 Januari 2013.

http://megapasar.com/2012/10/16/target-kuasai-pasar-semen-gresik-tetapkan-strategi distribusi/. Diakses Tanggal : 15 Januari 2013. 